\title{
A genome-wide inventory of neurohormone GPCRs in the red flour beetle Tribolium castaneum
}

\author{
Frank Hauser ${ }^{\text {a }}$, Giuseppe Cazzamali ${ }^{\text {a }}$, Michael Williamson a , Yoonseong Park ${ }^{\text {b }, ~ B i n ~ L i ~}{ }^{\text {b, }}$ \\ Yoshiaki Tanaka ${ }^{c}$, Reinhard Predel ${ }^{\mathrm{d}}$, Susanne Neupert ${ }^{\mathrm{d}}$, Joachim Schachtner ${ }^{\mathrm{e}}$, \\ Peter Verleyen ${ }^{\mathrm{f}}$, Cornelis J.P. Grimmelikhuijzen ${ }^{\mathrm{a}, *}$ \\ ${ }^{a}$ Center for Functional and Comparative Insect Genomics; and Department of Cell Biology and Comparative Zoology, Institute of Biology, \\ University of Copenhagen, Universitetsparken 15, DK-2100 Copenhagen, Denmark \\ b Department of Entomology, Kansas State University, Manhattan, KS 66506-4004, USA \\ ${ }^{c}$ National Institute of Agrobiological Science, Division of Insect Science, Tsukuba, Ibaraki 305-8634, Japan \\ d Institute of General Zoology, University of Jena, Erbertstrasse 1, D-07743 Jena, Germany \\ ${ }^{\mathrm{e}}$ Department of Animal Physiology, University of Marburg, Karl-von-Frisch Strasse 8, D-35032 Marburg, Germany \\ ${ }^{\mathrm{f}}$ Department of Animal Physiology and Neurobiology, University of Leuven, Naamsestraat 59, BE-3000 Leuven, Belgium
}

Available online 24 October 2007

\begin{abstract}
Insect neurohormones (biogenic amines, neuropeptides, and protein hormones) and their G protein-coupled receptors (GPCRs) play a central role in the control of behavior, reproduction, development, feeding and many other physiological processes. The recent completion of several insect genome projects has enabled us to obtain a complete inventory of neurohormone GPCRs in these insects and, by a comparative genomics approach, to analyze the evolution of these proteins. The red flour beetle Tribolium castaneum is the latest addition to the list of insects with a sequenced genome and the first coleopteran (beetle) to be sequenced. Coleoptera is the largest insect order and about $30 \%$ of all animal species living on earth are coleopterans. Some coleopterans are severe agricultural pests, which is also true for $T$. castaneum, a global pest for stored grain and other dried commodities for human consumption. In addition, T. castaneum is a model for insect development. Here, we have investigated the presence of neurohormone GPCRs in Tribolium and compared them with those from the fruit fly Drosophila melanogaster (Diptera) and the honey bee Apis mellifera (Hymenoptera). We found 20 biogenic amine GPCRs in Tribolium (21 in Drosophila; 19 in the honey bee), 48 neuropeptide GPCRs (45 in Drosophila; 35 in the honey bee), and 4 protein hormone GPCRs (4 in Drosophila; 2 in the honey bee). Furthermore, we identified the likely ligands for 45 of these 72 Tribolium GPCRs. A highly interesting finding in Tribolium was the occurrence of a vasopressin GPCR and a vasopressin peptide. So far, the vasopressin/GPCR couple has not been detected in any other insect with a sequenced genome (D. melanogaster and six other Drosophila species, Anopheles gambiae, Aedes aegypti, Bombyx mori, and A. mellifera). Tribolium lives in very dry environments. Vasopressin in mammals is the major neurohormone steering water reabsorption in the kidneys. Its presence in Tribolium, therefore, might be related to the animal's need to effectively control water reabsorption. Other striking differences between Tribolium and the other two insects are the absence of the allatostatin-A, kinin, and corazonin neuropeptide/receptor couples and the duplications of other hormonal systems. Our survey of 340 million years of insect neurohormone GPCR evolution shows that neuropeptide/receptor couples can easily duplicate or disappear during insect evolution. It also shows that Drosophila is not a good representative of all insects, because several of the hormonal systems that we now find in Tribolium do not exist in Drosophila.
\end{abstract}

(C) 2007 Elsevier Inc. All rights reserved.

Keywords: GPCR; Neurohormone; Neuropeptide; Biogenic amine; Monoamine; Glycoprotein hormone; Insect; Agriculture; Genomics; Evolution

\footnotetext{
Nucleotide sequence data reported here are available in the CoreNucleotide or Third Party Annotation Section of the DDBJ/EMBL/GenBank databases under the Accession Nos: BK005734, BK005856-BK005875, and BK006093-BK006111.

* Corresponding author. Address: Department of Cell Biology and Comparative Zoology, Universitetsparken 15, DK-2100 Copenhagen, Denmark. Fax: +4535321200 .

E-mail address: cgrimmelikhuijzen@bi.ku.dk (C.J.P. Grimmelikhuijzen).
} 


\section{Introduction}

Insects are the largest animal group living on earth $(75 \%$ of all animal species are insects) and are extremely important for agriculture and ecology, because $70 \%$ of all flowering plants depend on insects for their pollination. Insects, however, can also be severe agricultural pests, destroying $30 \%$ of our potential annual harvest and can be the vectors for major diseases, such as malaria, which causes 1.5-2.7 million deaths each year.

Because of the importance of insects, 24 insect genome projects have been initiated during the last 8 years and several of them have been completed. These insects with a genome project are listed in Fig. 1 and are either medically or agriculturally important, or are model organisms (such as Drosophila). The most recent addition to the list of insects with a fully sequenced genome is the red flour beetle Tribo-

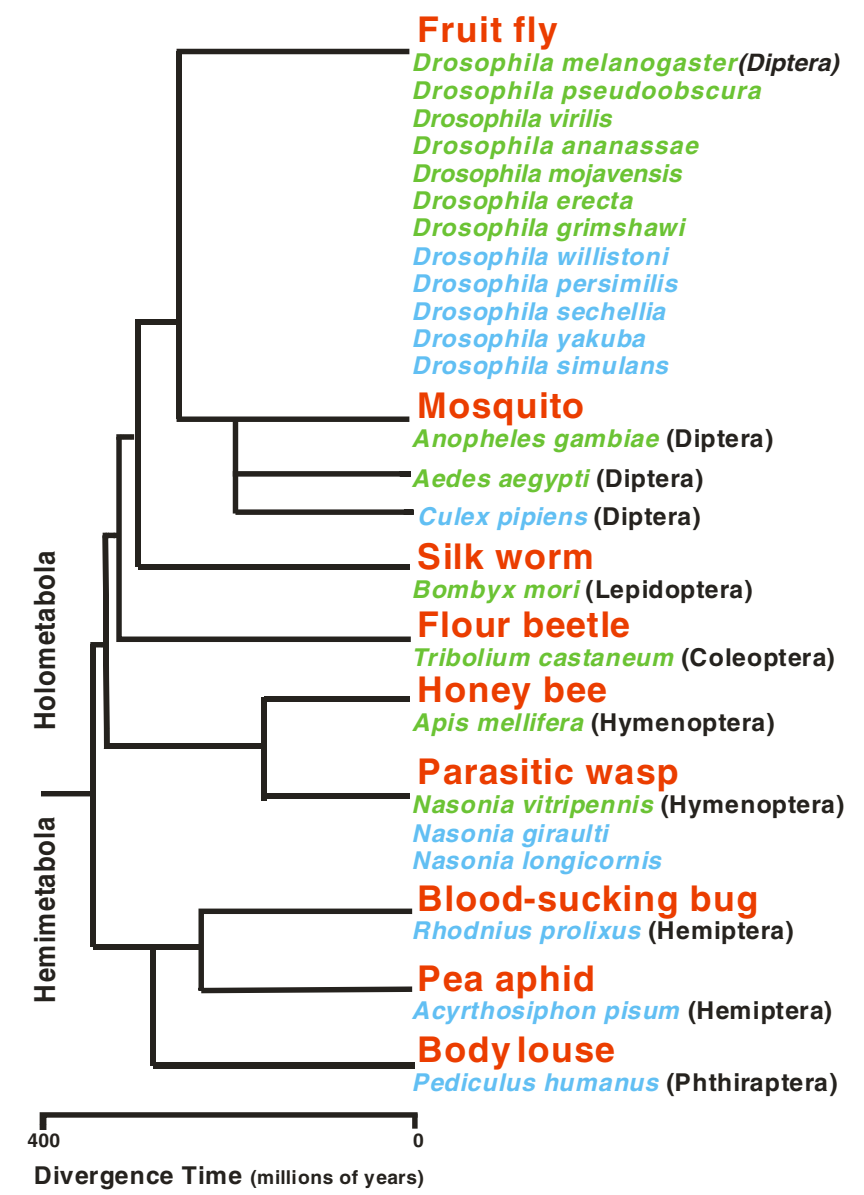

Fig. 1. The evolutionary relationships of insects for which genome projects exist. Insects whose genome has been completely sequenced (to at least 8-9 times coverage) are highlighted in green. Insects for which the genome sequence is still incomplete (less than 8 times coverage, as of July 2007) are highlighted in blue. The divergence times (the evolutionary distances in time between each species and the common ancestor with its neighbour in this figure) are given as horizontal bars and are from data presented in $[139,162]$, or in the various relevant "white papers" accessible on the internet. The completed insect genomes are published in $[1,62,111,115,133,162,166]$ (colors in this figure can only be seen in the online version of the article). lium castaneum [134]. Tribolium belongs to the insect order Coleoptera (or beetles), which is the largest insect order and which comprises about $40 \%$ of all insect species. Thus, about $30 \%$ of all animal species living on earth are coleopterans.

Insects can be subdivided into Holometabola (insects with a complete metamorphosis, from larvae to pupae to adults) and Hemimetabola (insects with an incomplete metamorphosis, where the larvae, also called nymphae, resemble the adults). So far, only the genomes from holometabolous insects have been fully sequenced (Fig. 1).

The Holometabola consist of four major insect orders, the most basal being Hymenoptera (to which honey bees, wasps and ants belong), followed by Coleoptera, Lepidoptera (butterflies and moths), and Diptera (flies) $[139,162]$. The evolutionary distance between Hymenoptera and Diptera is about 340 million years [33,139], a distance comparable to that between bony fishes and humans.

Tribolium has been selected for a genome project, because it is agriculturally important and a major global pest of stored grain, flour and many other dried and stored commodities for human consumption. Furthermore, Tribolium is a versatile genetic model for studies of eukaryotic development (http://www.hgsc.bcm.tmc.edu/projects/ tribolium/TriboliumWhitePaper.pdf). The size of the Tribolium genome is about $190 \mathrm{Mb}$ and it contains more than 16,400 genes [134].

The genomic data from Tribolium are highly relevant not only for our understanding of the biology of Tribolium, but also for the understanding of the other coleopterans, which comprise about 600,000 species. One would naively expect that the results from the Tribolium Genome Project would be somewhat intermediate between those from the more primitive honey bee (Hymenoptera) and the more advanced fruitfly (Diptera). However, as we can read in this review, each insect group has specialized itself and adapted to its ecological niche. As a consequence, Tribolium has obtained (or retained) characteristics that can not be found in the honey bee or in Drosophila.

$\mathrm{G}$ protein-coupled receptors (GPCRs) ${ }^{1}$ are the largest superfamily of transmembrane proteins in metazoans and up to $1-2 \%$ of all genes in an animal's genome code for GPCRs [43]. GPCRs have seven $\alpha$-helical transmembrane domains and are, therefore, also called seven transmem-

\footnotetext{
1 Abbreviations used: AKH, adipokinetic hormone; BCM, Baylor College of Medicine, Houston, USA; CCAP, crustacean cardioactive peptide; CHO, Chinese hamster ovary; CRF, corticotropin releasing factor; CT, calcitonin; DH, diuretic hormone; DLGR, Drosophila leucinerich repeats-containing GPCR; ETH, ecdysis triggering hormone; GFP, green fluorescent protein; GPCR, G protein-coupled receptor; GPA2, glycoprotein hormone alpha2; GPB5, glycoprotein hormone beta5; ic3, intracellular loop-3; LGR, leucine-rich repeats-containing GPCR; LRR, leucine-rich repeat; MIP, myoinhibitory peptide; MS, mass spectrometry; MYR, million years; NPF, neuropeptide F; na, not applicable or annotated; OT, oxytocin; PDF, pigment dispersing factor; sNPF, short neuropeptide F; TSH, thyroid stimulating hormone; 7TM, seven transmembrane; V1a, vasopressin 1a.
} 
brane, or 7TM receptors. They interact at their cytoplasmic loops with G proteins, leading to second messenger cascades [46]. GPCRs and their $G$ proteins even occur in plants and prokaryotes, showing that these signaling systems are evolutionarily very old $[50,101]$.

Our research group is especially interested in neurohormone GPCRs and their ligands (biogenic amines, neuropeptides and protein hormones), because these molecules occupy a central position in the physiology of animals and steer important processes, such as behavior, reproduction, and development. Neurohormone GPCRs are an important, but only smaller subset of the large GPCR superfamily. These GPCRs belong to two subfamilies, family-A (family-1, or rhodopsin-like) GPCRs, and family-B (family-2, or calcitonin-like) GPCRs [46]. The biogenic amine GPCRs belong to family-A, whereas the neuropeptide and protein hormone GPCRs cover both families. Because the Drosophila genome was the first insect genome to be sequenced [1], most information on insect neurohormone GPCRs is available from Drosophila [56,57].

In general, after an insect genome has been sequenced and assembled, software programs are applied to predict all the genes present in the genome and, by comparison with genes already identified from other genomes, to propose a function for these genes (annotations). These automated annotations have, of course, to be verified by manual curation and subsequent experimental approaches, such as PCR and cloning. Shortly after the publication of the Drosophila genome [1], Hewes and Taghert [59] annotated 21 genes as coding for biogenic amine GPCRs and 44 genes for neuropeptides and protein hormone GPCRs. During the last few years, we have found 5 additional neuropeptide GPCRs, bringing the total number of neurohormone GPCRs in Drosophila first to 69 [56,57], and now to 70 (present paper, Figs. 2-4). Already before the publication of the Drosophila genomic sequence [1], a few neuropeptide and biogenic amine GPCRs had been cloned and their ligands determined. The publication of the Drosophila genome, however, has greatly boosted this line of research and currently the ligands for 17 biogenic amine GPCRs and 31 neuropeptide and protein hormone GPCRs have experimentally been identified [57]. Thus, for 48 or nearly $70 \%$ of all Drosophila neurohormone GPCRs, the ligands are known (we say that these Drosophila GPCRs have been deorphanized). Although the remaining $30 \%$ of these Drosophila GPCRs are certainly more difficult to deorphanize, we are confident that this will happen and that we will have a rather complete picture of Drosophila GPCRs and their ligands within the next few years.

To deorphanize a neurohormone GPCR, its cDNA has to be cloned and its coding region expressed in cultured mammalian cells or Xenopus oocytes [25,26,57]. The transformed cells are then exposed to peptides or other ligands from a chemical library or to a tissue extract containing the ligand. When a second messenger response occurs (or an ion current in the case of oocytes), we have a bioassay enabling the ligands to be purified and identified. There are many ways to measure the various second messenger responses or to manipulate the host cells in such a way that they are optimally reacting to GPCR activation by its ligand. Our research group has especially applied a technique, originally developed by Stables et al. [146], where Chinese hamster ovary $(\mathrm{CHO})$ cells are transfected with both DNA coding for a "universal" (or "promiscuous") G protein $\alpha$ subunit, $\mathrm{G} \alpha-16$, and DNA for the insect GPCR. Activation of $\mathrm{G} \alpha-16$ in these cells leads to an increase in intracellular $\mathrm{Ca}^{2+}$ concentration, which is measured as a strong (up to $400 \times$ over background) bioluminescence response [57]. More than half of the above-mentioned 48 identified Drosophila receptors has been deorphanized with this technique by us and other groups.

Our increased knowledge of Drosophila neurohormone GPCRs and their ligands strongly contributes, of course, to our understanding of Drosophila. This understanding of Drosophila's neurobiology and endocrinology will be further improved by the application of genetic tools such as the knocking-out of GPCR and neuropeptide genes. Since a few years, there has existed a Drosophila Gene Disruption Project, where, using P-element or piggyBac insertions, more than half of all Drosophila genes have been disrupted (http://flypush.imgen.bcm.tmc.edu/pscreen/). The current collection of mutants also contains flies with disrupted neurohormone GPCR and neuropeptide genes and it can be expected that the phenotypic characterization of these Drosophila mutants will teach us much about the functioning of the neurohormone/GPCR couples. This will certainly challenge many of the existing paradigms in insect neuroendocrinology.

One can expect that Drosophila neurohormone GPCRs will become a reference for our understanding and interpretation of other insect neurohormone GPCRs. For example, in a previous review on honey bee neurohormone GPCRs, we have used the Drosophila GPCRs as a "gold standard" to annotate the honey bee orthologues [57]. On the other hand, Drosophila can not be regarded as a perfect representative of all holometabolous insects and there are many biological processes absent in Drosophila that exist in other insects and vice versa. To obtain a better insight into the biology of insects, therefore, it is crucial also to investigate representatives of other insect orders and to study them with the same rigorousness as in Drosophila. The first step in this direction is the sequencing of their genomes (Fig. 1), followed by proper annotation and analysis of their genes.

In our current review, we have annotated the neurohormone GPCR genes in the first beetle with a sequenced genome, the red flour beetle Tribolium, using mainly Drosophila GPCR genes as a reference. Furthermore, we have compared these results with the neurohormone GPCR genes present in the honey bee and fruitfly. Tribolium is living in very dry surroundings and it can be expected that its endocrine system is organized in a different way from that of Drosophila. Therefore, we have 


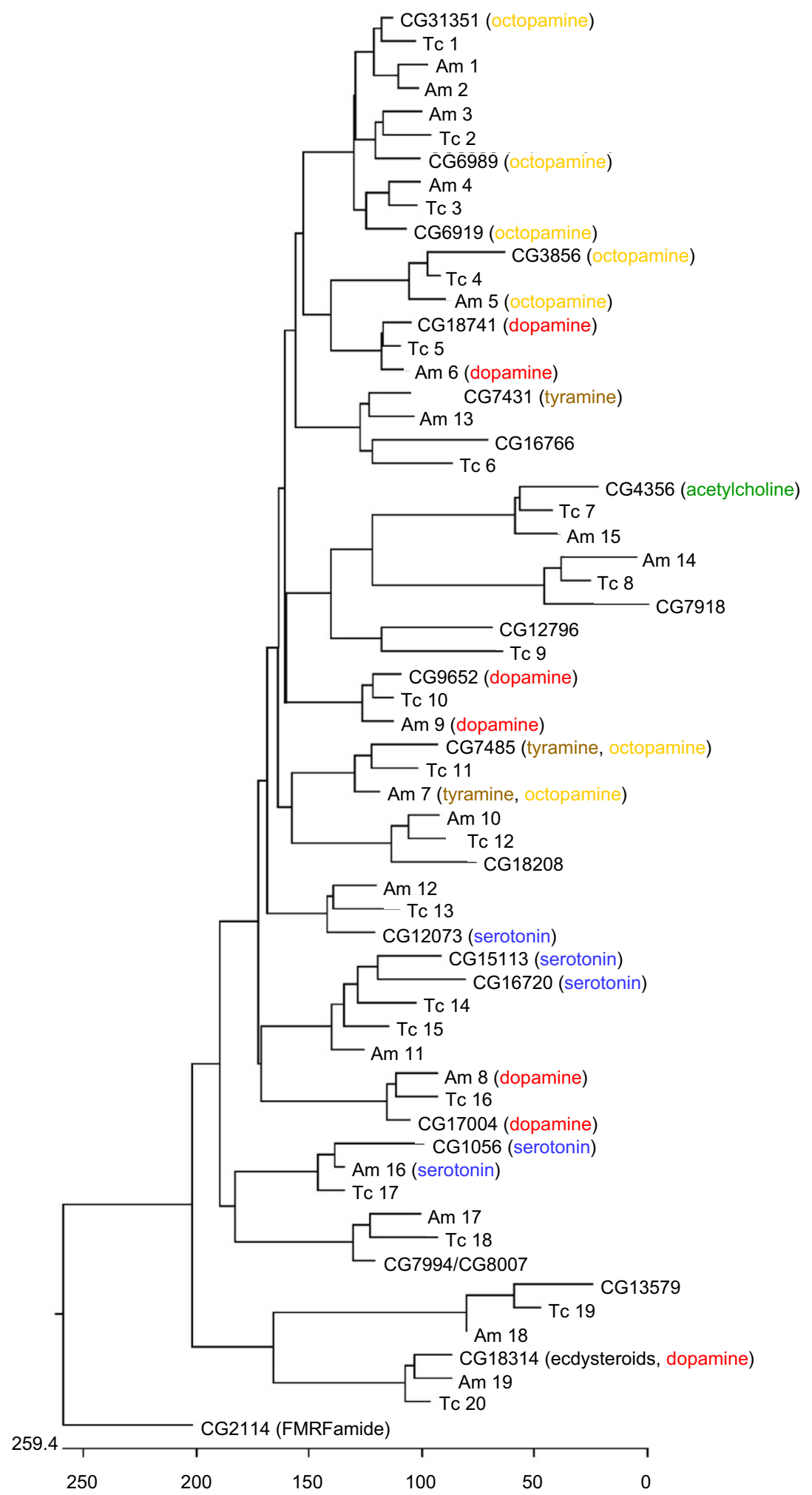

Fig. 2. Phylogenetic tree analysis of biogenic amine GPCRs from Drosophila (indicated by a CG number), T. castaneum (Tc 1-Tc 20), and A. mellifera (Am 1-Am 19). The tree is rooted by the Drosophila FMRFamide receptor CG2114. When a ligand has been experimentally identified for a GPCR and the GPCR thus has been deorphanized, this ligand is given in parentheses. We have highlighted identical ligands with the same color. The biogenic amine GPCRs belong to the rhodopsin- (or family A- or -1) type of GPCRs.

not only used Drosophila GPCRs for our TBLASTN searches, but also GPCRs from several other animals, including mammals.
In a recent paper, we have determined the occurrence of neuropeptides and protein hormone genes in the genome of Tribolium and we have also experimentally 
confirmed the presence of many of these neurohormones, using mass spectrometry [100]. A summary of these neurohormone findings is given in Table 1 . We found that our current neurohormone GPCR annotations perfectly fit to the independently annotated neurohormones. The outcome from the two studies is highly relevant for our understanding of the neurobiology of Tribolium. They also give us excellent insights into the evolution of

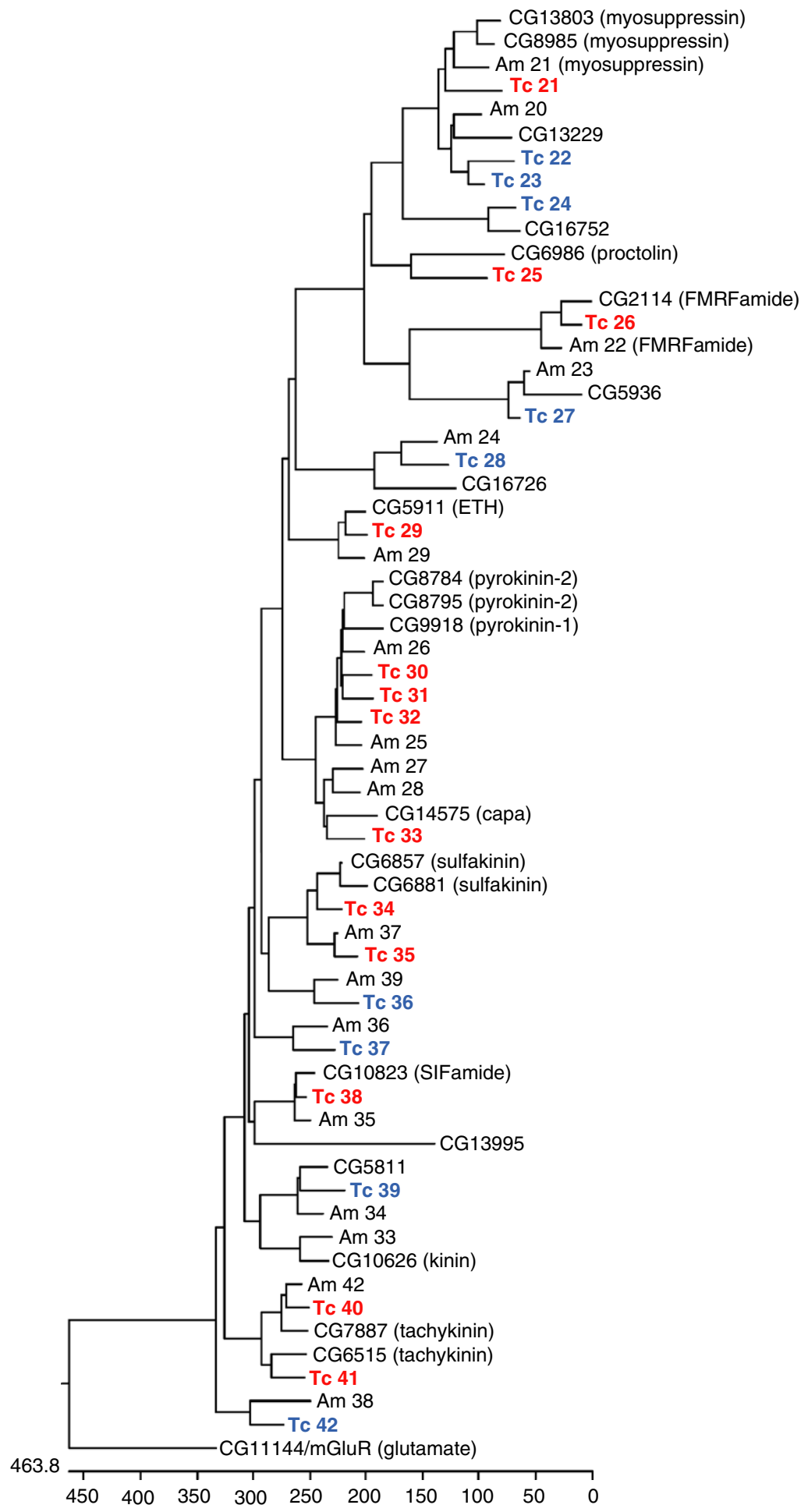

Fig. 3A. (A and B) Phylogenetic tree analysis of neuropeptide and protein hormone GPCRs, belonging to GPCR family A. The Drosophila GPCRs are indicated by a CG number, the receptors from T. castaneum by Tc 21-Tc 64, and the receptors from A. mellifera by Am 20-Am 52. The tree is rooted by the Drosophila metabotropic glutamate receptor CG11144. When the Tribolium receptor gene has a deorphanized orthologue in Drosophila and, thus, a likely ligand, it is highlighted in red. When no ligand can be assigned, it is highlighted in blue. The Tribolium vasopressin-like receptor gene Tc 45 is highlighted in green (top Fig. 3B), because it has an orthologue in mammals and not in Drosophila. 


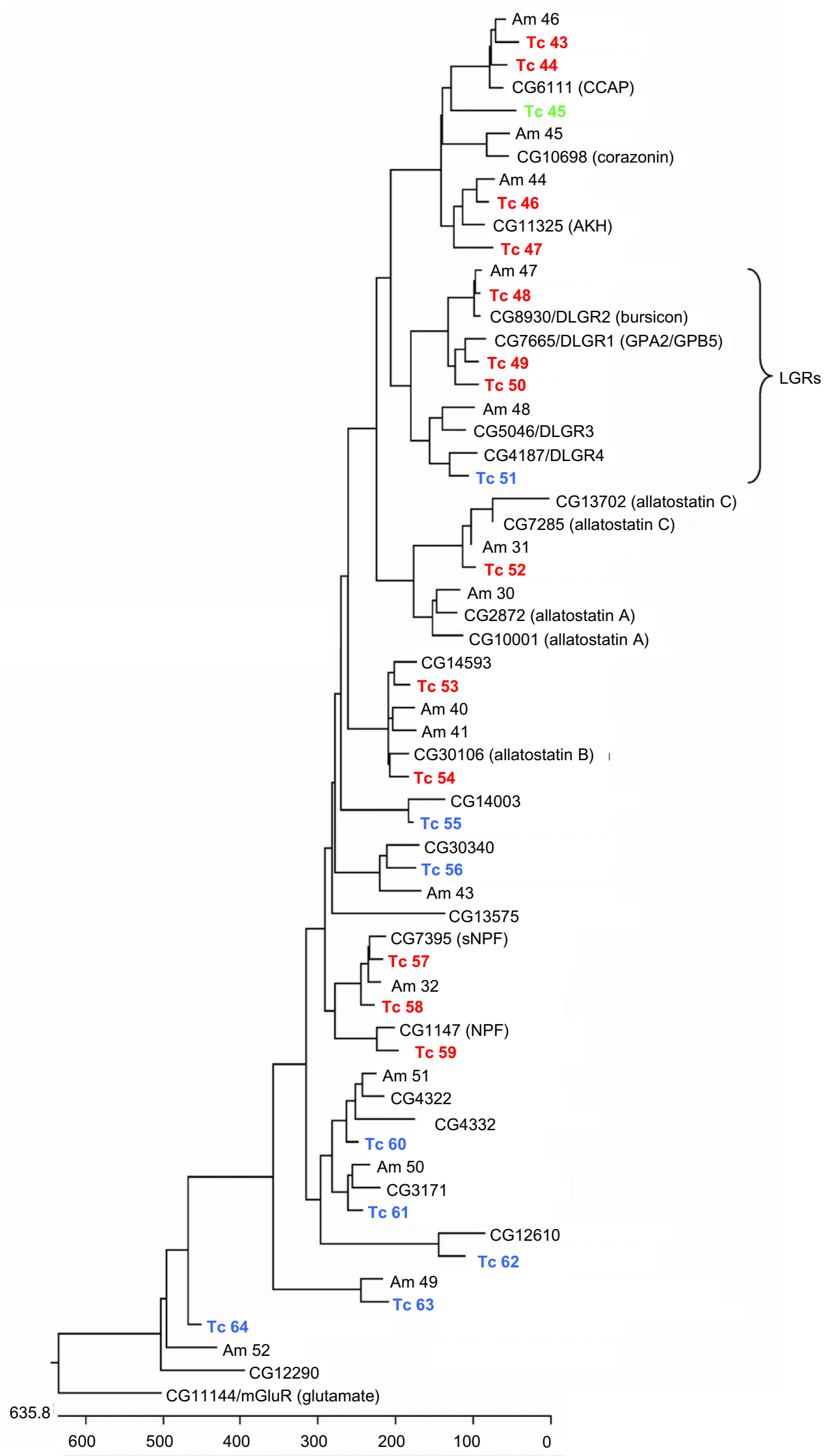

Fig. 3B. See legend for Fig. 3A. 


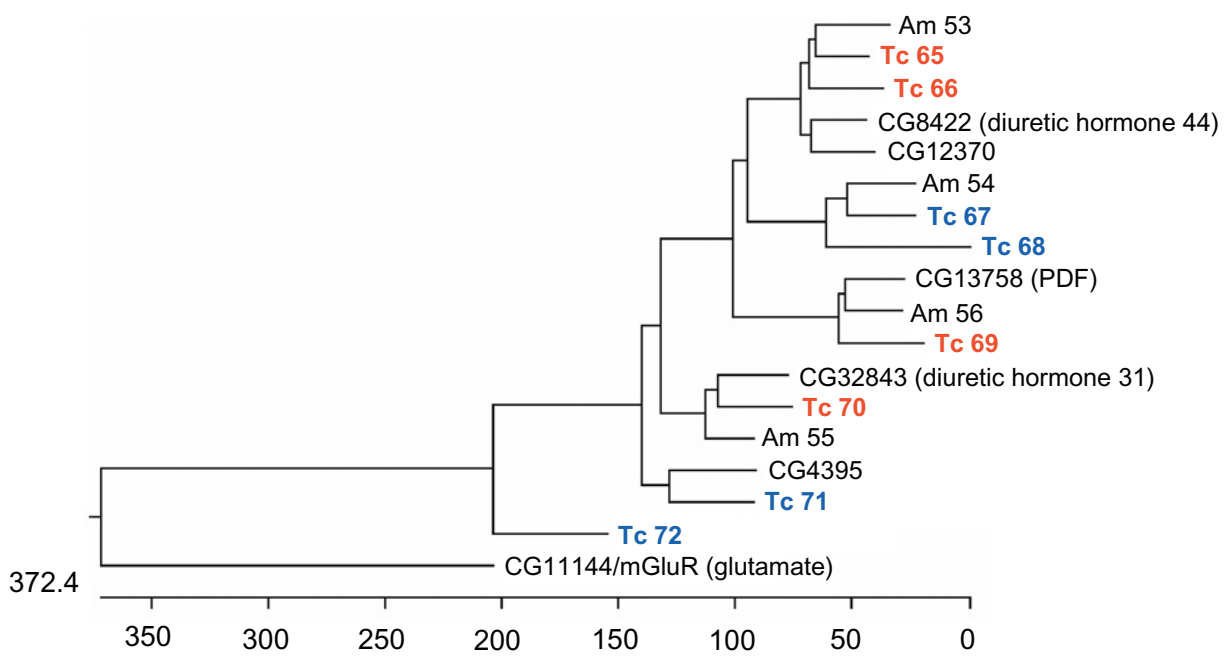

Fig. 4. Phylogenetic tree analysis of neuropeptide and protein hormone GPCRs, belonging to GPCR family B. The Drosophila GPCRs are indicated by a CG number, the receptors from T. castaneum by Tc 65-Tc 72, and the receptors from A. mellifera by Am 53-Am 56. The tree is rooted by the Drosophila metabotropic glutamate receptor CG11144. The receptor genes are highlighted in the same way as in Fig. 3.

neurohormone GPCRs in insects and their co-evolution with the ligands.

\section{Annotation strategies for GPCRs present in Tribolium}

The Tribolium genome was sequenced during 2004-2006 [134]. The results from several automated annotation pipelines and ab initio prediction programs were combined into a consensus set of 16,404 gene models, using the GLEAN software program in early 2006 [134].

We searched the complete Tribolium genome sequence (not the GLEAN set) with protein sequences corresponding to Drosophila, honey bee, and mammalian GPCRs, using the TBLASTN software program at the NCBI server http:// www.ncbi.nlm.nih.gov/sutils/genom_table.cgi?organism= insects. The regions that were hit with highest scores were checked for their presence in the GLEAN set, which was not always the case. Subsequently, they were manually curated and annotated at the Baylor College of Medicine (BCM) Tribolium annotation server under a GLEAN number.

Our annotation efforts led to the discovery of 20 Tribolium genes, coding for biogenic amine GPCRs (there are 21 Drosophila, and 19 honey bee biogenic amine GPCRs; Fig. 2), 44 neuropeptide and protein hormone GPCRs, belonging to family-A (there are 40 in Drosophila and 31 in the honey bee; Fig. 3), and 8 neuropeptide GPCRs, belonging to family-B (there are 5 in Drosophila and 4 in the honey bee; Fig. 4). For clarity, we have named these Tribolium neurohormone GPCRs Tc 1 to Tc 72 (Figs. 24). The GLEAN numbers, corresponding to these Tc numbers can be retrieved from Tables 2 and 3 .

We used three criteria for deciding whether a Tribolium gene is the orthologue of a Drosophila (or honey bee) neurohormone GPCR gene: (i) its gene product should have high amino acid sequence identity with the Drosophila neu- rohormone GPCR (more than 50\% in the 7TM region, see Tables 2 and 3); (ii) in a phylogenetic tree analysis, the Tribolium GPCR should lie "close" to the Drosophila GPCR (for example, the Tribolium receptor Tc 1 and the Drosophila octopamine receptor CG31351, top of Fig. 2, are clear orthologues); (iii) the genomic organizations should be similar (various identical intron positions, see Tables 2 and 3). For the other Tribolium GPCR genes that did not have a clear Drosophila or honey bee orthologue, the criterion for being a neurohormone GPCR gene was that it had a neurohormone GPCR orthologue in an other animal group, for example in mammals.

To obtain a quick overview of the neurohormone GPCRs in Tribolium, the reader is referred to the phylogenetic tree analyses (Figs. 2-4), which are quite illustrative. For example (top of Fig. 2), Tc 1 to Tc 4 are clearly octopamine receptors, Tc 5 is clearly a dopamine receptor, etc. These three figures contain, in addition to the Tribolium (indicated by Tc numbers) and Drosophila (CG-numbered) GPCRs, also the honey bee (Am-numbered) GPCRs for comparison [57]. In the following, we will discuss the GPCRs given in Figs. 2-4 in more detail.

\section{Biogenic amine GPCRs}

The known biogenic amines in insects that exert their actions via GPCRs are dopamine, tyramine, and octopamine (derived from tyrosine), serotonin (derived from tryptophane), and acetylcholine. The structures and biosynthetic pathways of tyramine and octopamine are given in [23].

Biogenic amines steer numerous behaviors and physiological processes in insects, among them learning, memory, sleep, arousal, honey bee dance, feeding, and diuresis $[7,11,14,48,119,135,143,161]$. As mentioned earlier, we found twenty biogenic amine GPCRs in Tribolium. Fig. 2 shows a phylogenetic tree analysis of these receptors, which 
Table 1

A summary of neuropeptides and protein hormones present in Tribolium

\begin{tabular}{|c|c|}
\hline Name (Trica-) & Structure \\
\hline $\begin{array}{l}\text { Adipokinetic hormone-1 } \\
\text { Adipokinetic hormone-2 } \\
\text { Adipokinetic hormone-3 }\end{array}$ & $\begin{array}{l}\text { pQLNFSTDWamide } \\
\text { pQLNFTPNWamide } \\
\text { pQVTFSRDWNPamide }\end{array}$ \\
\hline $\begin{array}{l}\text { Allatostatin B-1 } \\
\text { Allatostatin B-2 } \\
\text { Allatostatin B-3 } \\
\text { Allatostatin B-4 } \\
\text { Allatostatin B-5 } \\
\text { Allatostatin B-6 }\end{array}$ & $\begin{array}{l}\text { DWNKDLHIWamide } \\
\text { GWNNLHEGWamide } \\
\text { AWQSLQSGWamide } \\
\text { NWGQFHGGWamide } \\
\text { SKWDNFRGSWamide } \\
\text { EPAWSNLKGIWamide }\end{array}$ \\
\hline Allatostatin $\mathrm{C}$ & pQSRYRQCYFNPISCF \\
\hline Allatotropin & DAKYPQVRTPQQRLTRGIEALKYHNMDLGTARGYamide \\
\hline $\begin{array}{l}\text { Antidiuretic factor-1 } \\
\text { Antidiuretic factor-2 } \\
\text { Antidiuretic factor-3 } \\
\text { Antidiuretic factor-4 } \\
\text { Antidiuretic factor-5 }\end{array}$ & $\begin{array}{l}\text { HDDGSYKPHVYGW } \\
\text { YDDGSYKPHVYGF } \\
\text { YDDGSYKPHIYGF } \\
\text { YDDGSYKPGLYA } \\
\text { YDDGSYKPHIYGH }\end{array}$ \\
\hline $\begin{array}{l}\text { Bursicon } \alpha \text {-subunit } \\
\text { Bursicon } \beta \text {-subunit }\end{array}$ & $\begin{array}{l}\text { GLEAN_13832 } \\
\text { GLEAN_13831 }\end{array}$ \\
\hline $\begin{array}{l}\text { Capa-1 } \\
\text { Capa-2 }\end{array}$ & $\begin{array}{l}\text { EPKEPKRNKLASVYALTPSLRVamide } \\
\text { RIGKMVSFPRIamide }\end{array}$ \\
\hline $\begin{array}{l}\text { Crustacean cardioactive peptide } \\
\text { Diuretic hormone- } 31 \\
\text { Diuretic hormone- } 37 \\
\text { Diuretic hormone- } 47\end{array}$ & $\begin{array}{l}\text { PFCNAFTGCamide } \\
\text { GLDLGLGRGFSGSQAAKHLMGLAAANFAGGPamide } \\
\text { SPTISITAPIDVLRKTWAKENMRKQMQINREYLKNLQamide } \\
\text { AGALGESGASLSIVNSLDVLRNRLLLEIARKKAKEG- } \\
\text { ANRNRQILLSLamide }\end{array}$ \\
\hline Eclosion hormone & GLEAN_00178 \\
\hline
\end{tabular}

Predicted Confirmed

(o) $(+)$

$\begin{array}{ll}\mathrm{o} & \\ \mathrm{o} & + \\ \mathrm{o} & \\ \mathrm{o} & + \\ \mathrm{o} & + \\ \mathrm{o} & + \\ \mathrm{o} & + \\ \mathrm{o} & + \\ \mathrm{o} & + \\ \mathrm{o} & \\ \mathrm{o} & + \\ \mathrm{o} & \\ \mathrm{o} & \\ \mathrm{o} & \\ \mathrm{o} & \\ \mathrm{o} & \\ \mathrm{o} & \\ \mathrm{o} & \\ \mathrm{o} & + \\ \mathrm{o} & + \\ \mathrm{o} & \\ \mathrm{o} & + \\ \mathrm{o} & + \\ \mathrm{o} & + \\ & + \\ & +\end{array}$

Ecdysis-triggering hormone-1

NSNFLRFamide Ecdysis-triggering hormone-2

ENYVLKAAKNVPRIamide SNTNKNTNIDEMGKFFMKASKSVPRIamide

SGKIEKNDHFIRFamide

SKQDFLRFamide

NQPKATTNYLRFamide

DTSNFLRFamide

GLEAN_11941

GLEAN 12548

TC 030007

Ion transport peptide/crustacean hyperglycaemic hormone

Myosuppressin

pQDVDHVFLRFamide

Neuroparsin

GLEAN 13258

$+$

RYLPT

TC_030081

SESNWVPDDNSYGAQRPGANSGGMWFGPRLamide TPHESSVPNERNDDSKETYFWFGPRLamide

HVVNFTPRLamide

SPPFAPRLamide

HSSPFSPRLamide

TYRKPPFNGSIFamide

SGRSPSLRLRFamide

pQTSDDYGHLRFamide

GEEPFDDYGHMRFamide

APSGFTGVRamide

APSGFMGMRamide

APMGFMGMRamide

$+$

$+$ 
Table 1 (continued)

\begin{tabular}{|c|c|c|c|}
\hline Name (Trica-) & Structure & $\begin{array}{l}\text { Predicted } \\
\text { (o) }\end{array}$ & $\begin{array}{l}\text { Confirmed } \\
(+)\end{array}$ \\
\hline Tachykinin-4 & APSGFFGMRamide & o & + \\
\hline Tachykinin-5 & MPRQAGFFGMRamide & $\mathrm{o}$ & + \\
\hline Vasopressin & CLITNCPRGamide & o & \\
\hline
\end{tabular}

These sequences are predicted by bioinformatical tools (o) or experimentally confirmed by mass spectrometry $(+)$. For peptide and protein sequences with more than 50 residues, we refer to the GLEAN or gene number [134]. The data are derived from information given in [100].

also includes the Drosophila and honey bee biogenic amine GPCRs. Table 2 gives information on the amino acid residue identities between the Tribolium and Drosophila/honey bee orthologues and also compares their gene structures (intron/exon positions).

\subsection{Ligands can be assigned for fourteen Tribolium biogenic amine GPCRs}

When we used the above-mentioned criteria for orthologues, we found that all twenty biogenic amine GPCR genes in Tribolium have clear orthologues in Drosophila and honey bee (Fig. 2 and Table 2). Because seventeen Drosophila and five honey bee biogenic amine GPCRs have been deorphanized (Table 2), it is easy to assign the likely ligands for the corresponding fourteen Tribolium GPCRs (Fig. 2). Thus, Tc 1 to Tc 4 are octopamine receptors, Tc 5 is a dopamine receptor, Tc 7 is an acetylcholine receptor, Tc 10 is a dopamine receptor, Tc 11 is a tyramine/octopamine receptor, Tc 13 to Tc 15 are serotonin receptors, Tc 16 is a dopamine receptor, Tc 17 is a serotonin receptor, and Tc 20 is a dopamine receptor (Fig. 2 and Table 2). These assignments become even more convincing, where both the Drosophila and honey bee orthologues have been deorphanized. This is true for Tc 4, where both the Drosophila and honey bee orthologues are octopamine receptors; Tc 5, Tc 10, and Tc 16, where both the Drosophila and honey bee orthologues are dopamine receptors; Tc 11, where both the Drosophila and honey bee orthologues are tyramine/octopamine receptors; and Tc 17, where both the Drosophila and honey bee orthologues are serotonin receptors. There are no cases, where the Drosophila and honey bee orthologues use different ligands, which illustrates the reliability of our approach.

\subsection{No ligands can be assigned for six Tribolium biogenic amine GPCRs}

Six Tribolium GPCRs in Fig. 2 have orthologues in Drosophila and honey bee that have not been deorphanized. Thus, no ligands can be assigned for Tc $6, \mathrm{Tc} 8, \mathrm{Tc} 9$, Tc 12, Tc 18, and Tc 19 (Fig. 2).

\subsection{The overall picture of biogenic amine GPCRs in Tribolium}

In terms of numbers, the general picture for biogenic amine GPCRs in Tribolium looks very similar to that found in Drosophila and the honey bee. In four out of five (Tc 1, Tc 6, Tc 9, Tc 14, Tc 15) cases, where there was a difference between Drosophila and the honey bee, the pattern in Tribolium resembled more that of Drosophila. For example the honey bee has two paralogues, Am 1 and Am 2, whereas Tribolium has only one (Tc 1) just as Drosophila (CG31351; top of Fig. 2).

\section{Neuropeptide and protein hormone GPCRs}

The ligands for the neuropeptide and protein hormone GPCRs in Tribolium have been annotated in a companion paper and many of them have been confirmed by mass spectrometry [100]. Table 1 gives an overview of these neuropeptide and protein hormone ligands. As mentioned earlier, their GPCRs belong to two subfamilies, family-A and family-B. Below, we will discuss the two families combined.

\subsection{By comparing with Drosophila, ligands can be assigned} for 30 Tribolium neuropeptide and protein hormone GPCRs

\subsubsection{Tc 21 is a myosuppressin-like receptor gene}

Myosuppressins are neuropeptides that generally inhibit insect muscle contractions [60]. In some insects, the peptide also inhibits the prothoracic gland to secrete ecdysteroids, which are steroid hormones stimulating growth, mating and metamorphosis [167]. Myosuppressins are characterized by the consensus sequence $\mathrm{X}_{1} \mathrm{DVX}_{2} \mathrm{HX}_{3}$ FLRFamide [117,156]. Also Tribolium has a myosuppressin gene and the existence of a Tribolium myosuppressin peptide has been confirmed by mass spectrometry (MS) (Table 1) [100]. Tc 21 is probably the myosuppressin receptor: In a phylogenetic tree analysis (top of Fig. 3A) it is the orthologue of CG13803, CG84985, and Am 21, which all three have been identified by us and others as specific myosuppressin receptors [35, 73, Rudolf and Grimmelikhuijzen, unpublished results]. The orthologous relationships between the four receptor genes are corroborated by the presence of a common intron ( 1 out of 1$)$ with identical intron phasings, and reasonable sequence identities between the receptor proteins (Table 3). The insect myosuppressin receptors are highly selective and need the whole myosuppressin consensus sequence for activation. They do not cross-react with the below mentioned FMRFamidelike peptides $[35,142]$. 
Table 2

Identification of twenty Tribolium biogenic amine receptors

\begin{tabular}{|c|c|c|c|c|c|c|c|c|c|}
\hline $\begin{array}{l}\text { Tribolium } \\
\text { receptor } \\
\text { no. in the } \\
\text { text }\end{array}$ & $\begin{array}{l}\text { CG no. of } \\
\text { the } \\
\text { Drosophila } \\
\text { orthologue }\end{array}$ & $\begin{array}{l}\text { Endogenous } \\
\text { ligand for the } \\
\text { deorphanized } \\
\text { Drosophila } \\
\text { receptor }\end{array}$ & Gene ID no. & $\begin{array}{l}\text { Protein } \\
\text { region } \\
\text { identified }\end{array}$ & $\begin{array}{l}\text { Sequence identity between TM1- } \\
7 \text { of the Tribolium and the closest } \\
\text { Drosophila/Apis receptor proteins } \\
\text { (without ic3) }\end{array}$ & $\begin{array}{l}\text { No. of introns } \\
\text { in the } \\
\text { Tribolium gene } \\
\text { coding region }\end{array}$ & $\begin{array}{l}\text { No. of common introns } \\
\text { between the Tribolium and } \\
\text { Drosophila/Apis genes } \\
\text { (coding regions) }\end{array}$ & $\begin{array}{l}\text { Accession } \\
\text { no. for the } \\
\text { Tribolium } \\
\text { receptor }\end{array}$ & $\begin{array}{l}\text { Reference for the } \\
\text { deorphanized } \\
\text { Drosophila and/or } \\
\text { honey bee receptor }\end{array}$ \\
\hline Tc 1 & CG31351 & Octopamine & $\begin{array}{l}\text { GLEAN_12598 } \\
\text { GLEAN_12599 }\end{array}$ & Complete & $48(83) / 72(82)$ & 2 & $1 / 2$ & BK005856 & {$[106]$} \\
\hline Tc 2 & CG6989 & Octopamine & GLEAN_12597 & Complete & $68(75) / 69(75)$ & 0 & $0 / 0$ & BK005857 & {$[106]$} \\
\hline Tc 3 & CG6919 & Octopamine & GLEAN_12600 & Complete & $66(72) / 77(85)$ & 3 & $2 / 2$ & BK005858 & {$[5,106]$} \\
\hline Tc 4 & CG3856 & Octopamine & GLEAN_11639 & Complete & $51(70) / 62(80)$ & 7 & $2 / 2$ & BK005859 & {$[5,51,53]$} \\
\hline Tc 5 & CG18741 & Dopamine & GLEAN_00574 & Complete & $74(88) / 79(88)$ & 2 & $2 / 2$ & BK005860 & {$[38,52,68]$} \\
\hline Tc 6 & $\begin{array}{l}\text { CG7431, } \\
\text { CG16766 }\end{array}$ & $\begin{array}{l}\text { Tyramine, } \\
\text { orphan }\end{array}$ & GLEAN_12122 & Incomplete & na & na & na & BK005868 & {$[23]$} \\
\hline Tc 7 & CG4356 & Acetylcholine & GLEAN_04470 & Complete & $47(72) / 61(73)$ & 5 & $2 / 3$ & BK005871 & {$[118,144]$} \\
\hline Tc 8 & CG7918 & Orphan & GLEAN_00298 & Complete & $40(72) / 50(74)$ & 3 & $1 / 1$ & BK005869 & \\
\hline Tc 9 & CG12796 & Orphan & GLEAN_03331 & Complete & 42(48)/na(na) & $1 /-$ & $0 /-$ & BK005870 & \\
\hline Tc 10 & CG9652 & Dopamine & GLEAN_12447 & Complete & $81(89) / 76(85)$ & 4 & $2 / 2$ & BK005863 & {$[15,49,151]$} \\
\hline Tc 11 & CG7485 & $\begin{array}{l}\text { Octopamine/ } \\
\text { tyramine }\end{array}$ & GLEAN_04545 & Complete & $52(82) / 58(79)$ & 0 & $0 / 0$ & BK005861 & {$[3,16,137]$} \\
\hline Tc 12 & CG18208 & Orphan & $\begin{array}{l}\text { GLEAN_11641 } \\
\text { GLEAN_11643 }\end{array}$ & Complete & $55(73) / 68(67)$ & 2 & $1 / 2$ & BK005864 & \\
\hline Tc 13 & CG12073 & Serotonin & GLEAN_11667 & Complete & $57(76) / 54(76)$ & 1 & $0 / 0$ & BK005867 & {$[140,165]$} \\
\hline Tc 14 & CG15113 & Serotonin & GLEAN_11960 & Complete & $43(74) / 51(72)$ & 4 & $3 / 2$ & BK005865 & {$[138]$} \\
\hline Tc 15 & CG16720 & Serotonin & GLEAN_12297 & TMII-end & $38(72) / 56(70)$ & 2 & $2 / 1$ & BK005866 & {$[138]$} \\
\hline Tc 16 & CG17004 & Dopamine & GLEAN_07490 & Complete & $62(75) / 64(91)$ & 4 & $4 / 4$ & BK005862 & {$[8,58]$} \\
\hline Tc 17 & CG1056 & Serotonin & $\begin{array}{l}\text { GLEAN_13979 } \\
\text { GLEAN_13980 }\end{array}$ & Complete & $39(78) / 66(75)$ & 4 & $2 / 3$ & BK005872 & {$[31]$} \\
\hline Tc 18 & $\begin{array}{l}\text { CG7994, } \\
\text { CG8007 }\end{array}$ & Orphan & GLEAN_13982 & Complete & $42(78) / 53(83)$ & 6 & $2 / 3$ & BK005873 & \\
\hline Tc 19 & CG13597 & Orphan & GLEAN_01180 & Complete & $48(64) / 70(82)$ & 5 & $4 / 4$ & BK005874 & \\
\hline Tc 20 & CG18314 & $\begin{array}{l}\text { Ecdysteroids, } \\
\text { dopamine }\end{array}$ & GLEAN_06457 & Complete & $71(68) / 76(72)$ & 1 & $1 / 1$ & BK005875 & {$[145]$} \\
\hline
\end{tabular}

ic-3, intracellular loop-3; na, not annotated or applicable. 
Table 3

Identification of fifty-two Tribolium neuropeptide and protein hormone receptors

\begin{tabular}{|c|c|c|c|c|c|c|c|c|c|}
\hline $\begin{array}{l}\text { Tribolium } \\
\text { receptor } \\
\text { no. in the } \\
\text { text }\end{array}$ & $\begin{array}{l}\text { CG no. of } \\
\text { the } \\
\text { Drosophila } \\
\text { orthologue }\end{array}$ & $\begin{array}{l}\text { Endogenous } \\
\text { ligand for the } \\
\text { deorphanized } \\
\text { Drosophila } \\
\text { receptor }\end{array}$ & Gene ID no. & $\begin{array}{l}\text { Protein } \\
\text { region } \\
\text { identified }\end{array}$ & $\begin{array}{l}\text { Sequence identity between the } \\
\text { identified parts of the Tribolium and } \\
\text { the closest DrosophilalApis } \\
\text { orthologue (TM1-TM7) }\end{array}$ & $\begin{array}{l}\text { No. of introns in } \\
\text { the Tribolium } \\
\text { receptor gene } \\
\text { (coding region) }\end{array}$ & $\begin{array}{l}\text { No. of common introns } \\
\text { between the Tribolium and } \\
\text { DrosophilalApis genes } \\
\text { (coding regions) }\end{array}$ & $\begin{array}{l}\text { Accession } \\
\text { no. for the } \\
\text { Tribolium } \\
\text { receptor }\end{array}$ & $\begin{array}{l}\text { Reference for } \\
\text { the } \\
\text { deorphanized } \\
\text { Drosophila } \\
\text { receptor }\end{array}$ \\
\hline Tc 21 & $\begin{array}{l}\text { CG8985, } \\
\text { CG13803 }\end{array}$ & Myosuppressin & GLEAN_10505 & Complete & $37 / 38$ & 1 & $1 / 1$ & BK006094 & {$[35,73]$} \\
\hline Tc 22 & CG13229 & Orphan & GLEAN_11478 & Complete & $38 / 47$ & 1 & $1 / 1$ & BK006093 & \\
\hline Tc 23 & CG13229 & Orphan & GLEAN_15904 & Complete & $42 / 49$ & 2 & $1 / 1$ & BK006095 & \\
\hline Tc 24 & CG16752 & Orphan & GLEAN_02917 & Complete & $62 / \mathrm{na}$ & 2 & $1 /$ na & XM_970169 & \\
\hline Tc 25 & CG6986 & Proctolin & GLEAN_03492 & Complete & $28 /$ na & 4 & $2 /$ na & BK006096 & {$[36,74]$} \\
\hline Tc 26 & CG2114 & FMRFamides & GLEAN_01381 & Complete & $55 / 51$ & 1 & $0 / 1$ & BK006097 & {$[19,107]$} \\
\hline Tc 27 & CG5936 & Orphan & GLEAN_02524 & Complete & $51 / 66$ & 2 & $1 / 2$ & XM_963259 & \\
\hline Tc 28 & CG16726 & Orphan & GLEAN_07986 & TM 1-5 & $35 / 50$ & 0 & $0 / 0$ & & \\
\hline Tc 29 & CG5911 & $\begin{array}{l}\text { Edysis-triggering- } \\
\text { hormone }\end{array}$ & GLEAN_12493 & Complete & $70 / 60$ & 3 & $2 / 2$ & BK006098 & {$[71,123]$} \\
\hline Tc 30 & CG8795 & Pyrokinin-2 & GLEAN_11318 & Complete & $53 / 60$ & 3 & $2 / 2$ & BK006099 & {$[122,136]$} \\
\hline Tc 31 & CG8784 & Pyrokinin-2 & GLEAN_11320 & Complete & $50 / 58$ & 2 & $2 / 2$ & BK006100 & {$[122,136]$} \\
\hline Tc 32 & CG9918 & Pyrokinin-1 & GLEAN_11171 & Complete & $55 / 60$ & 3 & $3 / 2$ & BK006101 & {$[22]$} \\
\hline Tc 33 & CG14575 & Capa & GLEAN_07170 & Complete & $47 / 49$ & 5 & $3 / 3$ & BK006102 & {$[72,122]$} \\
\hline Tc 34 & CG6857 & Sulfakinin & GLEAN_08438 & Complete & $59 / 57$ & 4 & $2 / 3$ & XM_967657 & $\begin{array}{l}\text { [89, Kobberup } \\
\text { et al., } \\
\text { unpublished] }\end{array}$ \\
\hline Tc 35 & CG6857 & Sulfakinin & GLEAN_07536 & Complete & $50 / 79$ & 5 & $2 / 3$ & XM_970133 & $\begin{array}{l}{[89, \text { Kobberup }} \\
\text { et al., } \\
\text { unpublished }]\end{array}$ \\
\hline Tc 36 & na & na & GLEAN_14211 & Complete & $\mathrm{na} / 45$ & 5 & $\mathrm{na} / 4$ & XM_966369 & \\
\hline Tc 37 & na & na & GLEAN_09749 & Complete & $\mathrm{na} / 50$ & 4 & $\mathrm{na} / 4$ & XM_968645 & \\
\hline Tc 38 & CG10823 & SIFamide & GLEAN_11156 & Complete & $72 / 80$ & 3 & $3 / 2$ & BK005734 & {$[77]$} \\
\hline Tc 39 & CG5811 & Orphan & GLEAN_01056 & Complete & $49 / 48$ & 4 & $4 / 3$ & XM_970025 & \\
\hline Tc 40 & CG7887 & Tachykinin & GLEAN_11198 & Complete & $66 / 70$ & 5 & $2 / 1$ & XM_965009 & {$[12,99]$} \\
\hline Tc 41 & CG6515 & Tachykinin & GLEAN_04977 & Complete & $56 / 49$ & 8 & $5 /$ na & XM_966290 & {$[73,112]$} \\
\hline Tc 42 & na & na & GLEAN_09184 & Complete & $\mathrm{na} / 33$ & 4 & $\mathrm{na} / 3$ & XP_972230 & \\
\hline TC 43 & CG6111 & $\begin{array}{l}\text { Crustacean } \\
\text { cardioactive } \\
\text { peptide }\end{array}$ & GLEAN_13945 & Complete & $63 / 63$ & 7 & $5 / 5$ & BK006103 & {$[21]$} \\
\hline TC 44 & CG6111 & $\begin{array}{l}\text { Crustacean } \\
\text { cardioactive } \\
\text { peptide }\end{array}$ & GLEAN_02216 & Complete & $68 / 65$ & 6 & $4 / 5$ & BK006104 & {$[21]$} \\
\hline Tc 45 & na & na & GLEAN_16363 & Complete & $\mathrm{na} / \mathrm{na}$ & 5 & $\mathrm{na} / \mathrm{na}$ & BK006105 & \\
\hline Tc 46 & CG11325 & Adipokinetic & GLEAN_09772 & Complete & $53 / 70$ & 6 & $3 / 6$ & DQ422965 & {$[55,148]$} \\
\hline
\end{tabular}




\begin{tabular}{|c|c|c|c|c|c|c|c|c|c|}
\hline Tc 47 & CG11325 & $\begin{array}{l}\text { Adipokinetic } \\
\text { hormone }\end{array}$ & GLEAN_01245 & Complete & $42 / 46$ & 7 & $1 / 3$ & BK006106 & {$[55,148]$} \\
\hline Tc 48 & $\begin{array}{l}\text { CG8930 } \\
\text { (DLGR2) }\end{array}$ & Bursicon & GLEAN_08163 & TM 1-7 & $85 / 85$ & 15 & $12 / 11$ & BK006107 & {$[37,104,108]$} \\
\hline Tc 49 & $\begin{array}{l}\text { CG7665 } \\
\text { (DLGR1) }\end{array}$ & GPA2/GPB5 & GLEAN_09127 & N-TM 1-7 & $68 /$ na & 13 & $12 /-$ & BK006111 & {$[54,150]$} \\
\hline Tc 50 & $\begin{array}{l}\text { CG7665 } \\
\text { (DLGR1) }\end{array}$ & GPA2/GPB5 & GLEAN_09575 & $\begin{array}{l}\text { N-TM 1- } \\
7\end{array}$ & $55 /$ na & 12 & 9/- & BK006108 & {$[54,150]$} \\
\hline Tc 51 & $\begin{array}{l}\text { CG4187 } \\
\text { (DLGR4) }\end{array}$ & Orphan & GLEAN_15777 & $\begin{array}{l}\text { N-TM 1- } \\
7\end{array}$ & $56 /$ na & 18 & $14 /-$ & BК006109 & \\
\hline Tc 52 & CG13702 & Allatostatin-C & GLEAN_12842 & Complete & $57 / 67$ & 1 & $0 / 0$ & BK006110 & [88] \\
\hline Tc 53 & CG14593 & Orphan & GLEAN_06805 & Complete & $60 /$ na & 4 & $2 / \mathrm{na}$ & XP_974786 & \\
\hline Tc 54 & CG30106 & Allatostatin-B & GLEAN_05327 & Complete & $60 / 57$ & 5 & $4 / 3$ & XP_974772 & [73] \\
\hline Tc 55 & CG14003 & Orphan & GLEAN_14731 & Complete & $58 /$ na & 6 & $5 /$ na & XP_975121 & \\
\hline Tc 56 & CG30340 & Orphan & GLEAN_02497 & TM1-7 & $49 / 41$ & 3 & $2 / 1$ & XP_970905 & \\
\hline Tc 57 & CG7395 & $\begin{array}{l}\text { Short } \\
\text { neuropeptide-F }\end{array}$ & GLEAN_03151 & Complete & $68 / 70$ & 0 & $0 / 0$ & XP_966794 & {$[39,109]$} \\
\hline Tc 58 & CG7395 & $\begin{array}{l}\text { Short } \\
\text { neuropeptide-F }\end{array}$ & GLEAN_03150 & Complete & $56 / 60$ & 0 & $0 / 0$ & XP_966881 & {$[39,109]$} \\
\hline Тc 59 & CG1147 & Neuropeptide F & GLEAN_11655 & Complete & $58 /$ na & 5 & $1 / \mathrm{na}$ & XP_967689 & [45] \\
\hline Tc 60 & CG4322 & Orphan & GLEAN_07687 & Complete & $56 / 51$ & 2 & $2 / 2$ & XP_974272 & \\
\hline Tc 61 & CG3171 & Orphan & GLEAN_04716 & Complete & $56 / 63$ & 4 & $3 / 2$ & XP_971005 & \\
\hline Tc 62 & CG12610 & Orphan & GLEAN_04565 & Complete & 45/na & 5 & 3/na & XP_967232 & \\
\hline Tc 63 & na & na & GLEAN_06608 & Complete & na/49 & 4 & na/0 & XP_974365 & \\
\hline Tc 64 & na & na & GLEAN_15120 & Complete & na/na & 1 & na/na & BK005853 & \\
\hline Tc 65 & CG8422 & $\begin{array}{l}\text { Diuretic hormone } \\
44\end{array}$ & GLEAN_07104 & Complete & $58 / 60$ & 8 & $7 / 8$ & XM_970323 & {$[75]$} \\
\hline Tc 66 & CG8422 & $\begin{array}{l}\text { Diuretic hormone } \\
44\end{array}$ & GLEAN_12799 & Complete & $53 / 52$ & 7 & $6 / 6$ & XM_966084 & [75] \\
\hline Tc 67 & na & na & GLEAN_10267 & Complete & $\mathrm{na} / 60$ & 9 & $\mathrm{na} / 4$ & XM_964860 & \\
\hline Tc 68 & na & na & GLEAN_08110 & Complete & $\mathrm{na} / 41$ & 4 & $\mathrm{na} / 2$ & XP_975039 & \\
\hline Tc 69 & CG13758 & $\begin{array}{l}\text { Pigment } \\
\text { dispersing factor }\end{array}$ & GLEAN_13682 & TM 2-7 & $50 / 53$ & 7 & $2 / 2$ & XP_971738 & {$[69,91,110]$} \\
\hline Tc 70 & CG32843 & $\begin{array}{l}\text { Diuretic hormone } \\
31\end{array}$ & GLEAN_02694 & Complete & $54 / 53$ & 7 & $7 / 7$ & XP_969030 & [76] \\
\hline Tc 71 & CG4395 & Orphan & GLEAN_13321 & Complete & 43/na & 7 & $3 / \mathrm{na}$ & & \\
\hline \multirow[t]{8}{*}{ Tc 72} & na & na & GLEAN_01222 & Complete & na & 7 & na/na & XP_968807 & \\
\hline & CG10626 & Kinin & & & & & & & [131] \\
\hline & CG10698 & Corazonin & & & & & & & [19] \\
\hline & $\begin{array}{l}\text { CG2872, } \\
\text { CG10001 }\end{array}$ & Allatostatins-A & & & & & & & [10,90,95-97] \\
\hline & CG4313 & Orphan & & & & & & & \\
\hline & CG12290 & Orphan & & & & & & & \\
\hline & CG13575 & Orphan & & & & & & & \\
\hline & CG13995 & Orphan & & & & & & & \\
\hline
\end{tabular}

na, not annotated or applicable. 


\subsubsection{Tc 25 is a proctolin-like receptor gene}

Proctolin is a small myo- and neurostimulatory peptide with the structure RYLPT [117]. Also Tribolium has a proctolin preprohormone gene (Table 1). The Tc 25 gene is probably the Tribolium receptor gene, because in a phylogenetic tree analysis (Fig. 3A) it is the orthologue of CG6986, which has been identified as the Drosophila proctolin receptor gene [36,74]. Moreover, the Tc 25 gene has two introns in common with CG6986 (Table 3). The two receptor proteins, however, have only modest amino acid sequence identities (Table 3). Both proctolin and its receptor are absent in the honey bee [57].

\subsubsection{Tc 26 is an FMRFamide-like receptor gene}

FMRFamides are small invertebrate neuropeptides with the C-terminal sequence FMRFamide or related sequences. In insects, these peptides are typically myoactive and stimulate for example larval body wall muscle contractions, but might also inhibit other muscles, for example the heart $[116,117,156]$. FMRFamides do also inhibit the production of ecdysteroids by the prothoracic gland [168]. Also Tribolium has an FMRFamide peptide gene that produces 5 different FMRFamides, all of which have been confirmed by MS (Table 1). None of these peptides has a myosuppressin consensus sequence and do, therefore, not cross-react with the insect myosuppressin receptors [35,142]. Tc 26 is likely to be the receptor for these FMRF amide peptides, as it is the clear orthologue of CG2114 and Am 22, which both have been identified as FMRFamide receptors [19, 107, Rudolf and Grimmelikhuijzen, unpublished results]. Moreover, Tc 26 has one (out of one) intron in common with the honey bee gene and the Tribolium, honey bee and Drosophila receptor proteins have high sequence identities (Table 3).

\subsubsection{Tc 29 is an ecdysis-triggering-hormone (ETH)-like receptor gene}

ETHs are small insect neuropeptides that initiate ecdysis behavior [83,84]. Each insect has usually two ETHs, which have the C-terminal consensus sequence KXV/IPRI/L/ Mamide [170]. Also Tribolium has an ETH gene, encoding two ETHs and the existence of both peptides has been experimentally confirmed by MS (Table 1). Tc 29 is probably the Tribolium ETH receptor, because it is a close orthologue of CG5911, which has been identified as an ETH receptor for both Drosophila ETH-1 and -2 [71,123]. Furthermore, Tc 29 has two introns (out of three) in common with CG5911 and the two receptor proteins have very high sequence identities (Table 1). CG5911 produces two receptor transcripts (CG5911-A and -B) by alternative splicing $[71,123]$. A similar splicing is also likely to occur with the Tc 26 transcripts. In Drosophila both the CG5911-A and -B encoded receptor variants bind ETH-1 and -2 , albeit with different affinities [71]. The two receptors are specific and do not get activated by other related neuropeptides such as the pyrokinins or capa peptides (see below).

\subsubsection{Tc 30, Tc 31 and Tc 32 are pyrokinin-like receptor genes}

The insect pyrokinins are neuropeptides with $\mathrm{C}$-terminal sequences that resemble that of the ETHs: FXPRLamide, where $\mathrm{X}$, however, is a small or hydrophilic amino acid residue $(\mathrm{X}=\mathrm{S}, \mathrm{T}, \mathrm{K}, \mathrm{A}$, or $\mathrm{G})$ and $\mathrm{L}$ is always an $\mathrm{L}$ (in contrast to the ETHs) [61,128]. The insect pyrokinins have very diverse actions, including the stimulation or induction of gut motility, sex hormone production, diapause, and pupariation $[2,61,63,117,128,158]$. The first insect pyrokinin receptors to be identified were those from Drosophila, where three pyrokinin receptors occur and two pyrokinin peptides $[22,122,136]$. Based on their differentiated affinities for the two pyrokinins, one receptor was named pyrokinin1 receptor (CG9918) activated by pyrokinin-1 (which has the $\mathrm{C}$ terminus WFGPRLamide), and the two other receptors were named pyrokinin-2 receptors (CG8784 and CG8795) activated nearly exclusively by pyrokinin-2 (which has the $\mathrm{C}$ terminus PFKPRLamide) $[22,136]$. Also Tribolium has two pyrokinin encoding genes, yielding at least five pyrokinins. Two of them are tentatively named pyrokinins-1 (having the $\mathrm{C}$ terminus WFGPRLamide) and three are tentatively named pyrokinins- 2 . The occurrence of the last three pyrokinins has also been confirmed by MS (Table 1). Tc 30, Tc 31, and Tc 32 probably encode Tribolium pyrokinin receptors, because they are close orthologues of CG8784, CG8795, and CG9918 (Fig. 3A). In addition, they have two introns (out of two or three) in common with the Drosophila pyrokinin receptor genes and their receptor proteins have high sequence identities with the three Drosophila receptors (Table 3). It is presently difficult to say which of the three receptors are pyrokinin-1 or -2 receptors. In Table 3 , therefore, they have tentatively been assigned to those Drosophila receptors with which they had highest amino acid residue identities. Furthermore, the Tc 32 gene had three introns just as the Drosophila pyrokinin-1 receptor gene CG9918, arguing that it is the Tribolium pyrokinin-1 receptor gene (Table 3).

\subsubsection{Tc 33 is a capa-like receptor gene}

The insect capa peptides resemble both the ETHs and pyrokinins and their C-terminal sequence is usually FPR Vamide. It is interesting that both in Drosophila and other insects the capa gene encodes a preprohormone containing two capa peptides and one or more pyrokinins-1 [80]. The physiological significance of this is currently unclear, as capa peptides do not stimulate the three Drosophila pyrokinin receptors, nor do pyrokinins stimulate the Drosophila capa receptor $[22,72,136]$. Capa peptides have a diuretic effect on the Malpighian tubules of Drosophila, but in other insects they might have antidiuretic or myotropic actions [80,120,125,127]. Also Tribolium has two peptides that resemble capa peptides (Table 1). That these two peptides are indeed capa peptides is supported by the finding that they are contained in a preprohormone together with a pyrokinin-1 [100]. Tc 33 is probably the Tribolium capa receptor, because in a phylogenetic tree analysis, it is the clear ortho- 
logue of CG14575, which has been identified as the Drosophila capa receptor [72]. Furthermore, Tc 33 has three introns in common with CG14575 and the two receptor proteins have high sequence identities (Table 3 ).

\subsubsection{Tc 34 and Tc 35 are sulfakinin-like receptor genes}

Sulfakinins are insect neuropeptides that are structurally related to mammalian cholecystokinin and gastrin and that, like their mammalian counterparts, also have a sulphated tyrosine residue [113]. Just like cholecystokinin and gastrin in mammals, sulfakinins inhibit food intake in insects $[105,160]$. Tribolium has two sulfakinins (Table 1). Tc 34 and Tc 35 (Fig. 3A) are probably Tribolium sulfakinin receptor genes, because they are the orthologues of the two Drosophila genes CG6857 and CG6881, which have previously been identified as the sulfakinin receptor genes [89, Kobberup and Hauser, unpublished]. The Tribolium genes have two common introns with their Drosophila orthologues and their receptor proteins have high sequence identities with their Drosophila counterparts (Table 3).

\subsubsection{Tc 38 is a SIFamide-like receptor gene}

SIFamide is a highly conserved neuropeptide with the C-terminal sequence SIFamide that has been isolated from various insects and crustaceans $[4,24,159,169]$. The physiological role of this peptide has been unknown, but recently it has been proposed that SIF amide is involved in Drosophila sexual behavior [153]. Also Tribolium has a SIFamide peptide (Table 1). Tc 38 is probably the Tribolium SIFamide receptor, because it is the close orthologue of CG10823 (Fig. 3A), which is the gene coding for the Drosophila SIFamide receptor [77]. Moreover, the two receptor genes have all three introns in common, and their receptor proteins have very high amino acid sequence identities (Table 3).

\subsubsection{Tc 40 and Tc 41 are tachykinin-like receptor genes}

Insect tachykinins are short neuropeptides that differ from mammalian tachykinins by their C-terminal consensus sequence, which is $\mathrm{FX}_{1} \mathrm{GX}_{2}$ Ramide, rather than FXGLMamide as in mammals. There are many different tachykinin isoforms in each insect, which are all encoded by a single gene, and which play various roles in neuronal signaling and gut activity $[117,126]$. Also Tribolium has six different tachykinins (Table 1). Tc 40 and Tc 41 are probably the Tribolium tachykinin receptor genes, because they are the close orthologues of CG7887 and CG6515 (Fig. 3A), which have been identified as the Drosophila tachykinin receptor genes $[12,73,99,112,124]$. Moreover, the two Tribolium receptor genes have several introns in common with their Drosophila orthologues and the receptor proteins show high amino sequence identities with their Drosophila counterparts (Table 3).

\subsubsection{Tc 43 and Tc 44 are CCAP-like receptor genes}

Crustacean cardioactive peptide (CCAP) is a small cyclic neuropeptide, activating heartbeat in crustaceans and insects $[34,40]$. In addition, CCAP plays a central role in ecdysis behavior in insects $[83,84]$. Also Tribolium has a CCAP that is fully identical with the crustacean CCAP (Table 1). Tc 43 and Tc 44 are probably the Tribolium CCAP receptor genes, as they are close orthologues of CG6111 (Fig. 3B, top), which has been identified as the Drosophila CCAP receptor gene [21]. In addition, Tc 43 has 4 (out of 6) and Tc 44 has 5 (out of 7) introns in common with CG6111 (Table 3). The encoded receptor proteins of Tc 43 and Tc 44 have high (63-68\%) amino acid sequence identities with their Drosophila counterparts (Table 3). It is interesting that Tribolium has two CCAP receptors compared to a single CCAP receptor in Drosophila and the honey bee (Fig. 3B).

\subsubsection{Tc 46 and Tc 47 are AKH-like receptor genes}

The insect adipokinetic hormones (AKHs) are a large family of neuropeptides that mobilize lipids and carbohydrates from the insect fat body during intense physical activities such as flight and locomotion [44]. In addition, AKHs play a critical role in carbohydrate homeostasis in Drosophila larvae [70,82]. Also Tribolium has three peptides belonging to the AKH family (Table 1). Tc 46 and Tc 47 are probably the Tribolium AKH receptors, because they are clear orthologues of CG11325 (Fig. 3B), which has been identified as the Drosophila AKH receptor $[55,122,148]$. Also, Tc 46 has three introns in common with CG11325 and 6 (out of 6) with Am 44, which has been identified as the honey bee AKH receptor gene [Haue and Grimmelikhuijzen, unpublished results]. Finally, the Tc 46 receptor protein has high amino acid sequence identities with the Drosophila (53\%) and especially the honey bee $(70 \%)$ receptors (Table 3$)$.

Although Tc 47 is a clear orthologue of CG11325 in our phylogenetic tree analysis (Fig. 3B), their gene structures show less resemblance: only 1 intron (out of 7 introns) is in common. When Tc 47 is compared with the honey bee AKH receptor gene, Am 44, it only shows 3 common introns (Table 3). Despite these differences, however, there is a considerable amount of amino acid sequence identities between the Tc 47 receptor and the AKH receptors from Drosophila (42\%) and honey bee (47\%) (Table 3), clearly suggesting that Tc 47 is an AKH-like receptor.

\subsubsection{Tc 48 is a bursicon-like receptor gene}

Bursicon is a heterodimeric protein hormone, consisting of an $\alpha$ - and $\beta$-subunit, which both have cystein-knot structures $[104,108,155]$. The hormone is responsible for the hardening and tanning of the initially soft cuticle shortly after hatching of an adult fly from its pupa $[41,42]$. Furthermore, bursicon is responsible for a behavioral motor program, causing wing expansion of the newly hatched adult insect, and it initiates apoptosis of the wing epithelial cells after this wing expansion has been completed $[67,85,103]$. Also the Tribolium genome contains two genes, one coding for a bursicon- $\alpha$ and another for a bursicon- $\beta$ subunit (Table 1). 
Our research group has originally cloned four Drosophila GPCRs that were evolutionarily related to the mammalian glycoprotein hormone receptors. Mammalian glycoprotein hormones, to which luteinizing hormone, choriogonadotropin, follicle stimulating hormone, thyroid stimulating hormone, and relaxin belong, and their GPCRs are all involved in various aspects of reproduction or development $[64,79,157]$. Like their mammalian counterparts, the Drosophila GPCRs are characterized by having a large, extracellular N-terminus containing a high number of leucine-rich repeats and were, therefore, called Drosophila leucine-rich repeats containing GPCRs, or DLGRs [37, 54, Bohn and Williamson, unpublished results]. Recently, one of these receptors, DLGR2 [37], has been deorphanized and identified as the Drosophila receptor for bursicon $[104,108]$.

Tc 48 is a very close orthologue of the Drosophila DLGR2 gene (CG8930) and, therefore, likely encodes the Tribolium bursicon receptor (Fig. 3B). Our phylogenetic tree analysis (Fig. 3B) also shows that the Tribolium, honey bee, and Drosophila bursicon receptor proteins are highly related, suggesting a strong evolutionary pressure to conserve the structure of these three proteins. In addition, the amount of sequence identities between the three proteins is very high $(85 \%$, Table 3$)$ and Tc 48 shares 12 introns (out of 15) with the Drosophila bursicon receptor gene (Table 3).

\subsubsection{Tc 49 and Tc 50 are glycoprotein hormone (GPA2/ GPB5)-like receptor genes}

In addition to the above-mentioned established mammalian glycoprotein hormone, thyroid stimulating hormone (TSH), another, novel glycoprotein hormone has recently been found to stimulate the mammalian TSH receptor. This hormone, named thyrostimulin, is a heterodimer of two novel glycoprotein hormone subunits, named GPA2 and GPB5 [114]. Also the Drosophila genome has two genes, one coding for a GPA2- and another for a GPB5-cystine-knot glycoprotein-like subunit [65]. Purified recombinant Drosophila GPA2/GPB5 heterodimers stimulated one of our previously cloned DLGRs, DLGR1, thereby deorphanizing this Drosophila receptor $[54,150]$. The physiological roles of DLGR1 and its heterodimeric GPA2/GPB5 ligand, however, remain elusive.

Also Tribolium has two genes, one encoding the Tribolium GPA2 and one encoding the GPB5 subunit (Table 1). Furthermore, Tribolium has two genes, Tc 49 and Tc 50, that are the close orthologues of CG7665, which is the Drosophila gene coding for DLGR1 (Fig. 3B). Thus, Tc 49 and Tc 50 are likely to be the genes coding for a Tribolium GPA2/GPB5 receptor. Tc 49 has 12 (out of 13) introns in common, and Tc 50 has 9 (out of 12) introns in common with CG7665 (Table 3). Furthermore, the two Tribolium receptor proteins have high percentage of amino acid sequence identities with the Drosophila GPA2/GPB5 receptor (55-68\%, Table 3). It is interesting that Tribolium has two paralogues compared to one in Drosophila, suggesting an important role for the GPA2/ GPB5 system in the beetle.

\subsubsection{Tc 52 is an allatostatin-C-like receptor gene}

The insect allatostatins are three distinct groups (-A, $-B$, and -C) of neuropeptides that have originally been isolated, because they could inhibit the synthesis and release of juvenile hormone by the corpora allata, two endocrine organs associated with the insect brain [149]. Juvenile hormone is a terpene important for insect development and reproduction. Allatostatin-C is a small cyclic neuropeptide originally isolated from the moth Manduca sexta (therefore it is also called $M$. sexta-type or lepidopteran allatostatin) [87] that also occurs in other insects, including Drosophila where its action, however, is unknown $[149,163]$. Also Tribolium has an allatostatin-C closely related to the Drosophila and $M$. sexta C-type allatostatins (Table 1) [149,163].

The Drosophila genes CG13702 and CG7285 have been identified as coding for the allatostatin-C receptors [88]. Tc 52 is a close orthologue of these two Drosophila genes (Fig. 3B) and, thus, likely codes for a Tribolium allatostatin-C receptor. Tc 52 has one intron in its coding region, which position, however, is different from those in the Drosophila and honey bee genes (Table 3).

\subsubsection{Tc 53 and Tc 54 are allatostatin-B-like receptor genes}

The allatostatic activities of B-type allatostatins were first established in crickets and these peptides are, therefore, also called cricket-type allatostatins [102]. B-type allatostatins occur in various insects, including Drosophila $[149,164]$. The B-type allatostatins are small neuropeptides with the $\mathrm{C}$-terminal $\mathrm{W}\left(\mathrm{X}_{6}\right)$ Wamide consensus sequence. In addition to their allatostatic actions in crickets, the B-type allatostatins have myoinhibitory properties in other insects, such as the locust Locusta migratoria and the moth M. sex$t a$ and are, therefore, also called MIPs (myoinhibitory peptides) $[13,141]$. Furthermore, the B-type allatostatins also have prothoracicostatic activity, inhibiting the release of ecdysteroids from the prothoracic gland during molting in lepidopterans [66]. Also Tribolium has 6 B-type allatostatins, which are all located on a single prohormone (Table 1) $[100]$.

The Drosophila gene CG30106 has been identified as an allatostatin-B receptor gene [73]. This gene has a paralogue, CG14593 (Fig. 3B) that, however, has remained an orphan, although it can be assumed that also this gene codes for an allatostatin-B receptor. Tc 53 and Tc 54 are close orthologues of CG30106 and, thus, likely code for Tribolium allatostatin-B receptors. Tc 54 has 4 introns (out of 5) in common with CG30106. The receptor proteins encoded by Tc 53 and Tc 54 have a high percentage of amino acid sequence identities with the Drosophila CG30106 and CG14593 receptors (58-60\%) (Table 3). 
4.1.16. Tc 57 and Tc 58 are short neuropeptide F-like receptor genes

Short neuropeptides F (sNPFs) are short insect neuropeptides (less than 10 amino acid residues long) with the C-terminal consensus sequence $\mathrm{PX}_{1} \mathrm{RLRX}_{2}$ amide (where $X_{1}=\mathrm{S}, \mathrm{Q}, \mathrm{M} ; X_{2}=\mathrm{F}$, W) [156]. These peptides appear to stimulate food intake and body size in Drosophila [93]. Also Tribolium has a sNPF (Table 1).

The Drosophila gene CG7395 has been identified as the gene coding for the Drosophila sNPF receptor $[39,109]$. Tc 57 and Tc 58 are the close orthologues of CG7395 and are likely to be the Tribolium genes coding for sNPF receptors (Fig. 3B). The coding regions of Tc 57 and Tc 58 have no introns just as their Drosophila and honey bee orthologues (Table 3). The two Tribolium receptor proteins share a high percentage of amino acid sequence identities with their Drosophila and honey bee counterparts (56-70\%) (Table 3).

\subsubsection{Tc 59 is a neuropeptide F-like receptor gene}

Drosophila neuropeptide F (NPF) is a 36 residues-long peptide with the C-terminal sequence RVRFamide that resembles mammalian neuropeptide $\mathrm{Y}[17,156]$. NPF has various roles in Drosophila: it stimulates feeding and sexual behavior, and dampens aggression [32,92]. NPF occurs in many insects other than Drosophila, but in Tribolium we were unable, so far, to identify the preprohormone gene for this peptide. At the receptor level, however, we find a clear Tribolium orthologue (Tc 59) of the Drosophila NPF receptor gene CG1147 [45] (Fig. 3B). The Tribolium receptor has high amino acid sequence identity (58\%) with the Drosophila receptor. However, their genes have only 1 intron (out of 5) in common (Table 3).

\subsubsection{Tc 65 and Tc 66 are diuretic hormone 44-like receptor genes}

There are two unrelated diuretic hormone genes in Tribolium, one yielding DH31 (also called calcitoninrelated DH or CT-DH) and one yielding two DHs (also called corticotropin-releasing-factor-related DH, or CRF$\mathrm{DH}$ ), originating from alternative splicing: DH37 and DH47 (Table 1) [100]. This situation in Tribolium is somewhat different from that in Drosophila, where the CRF-DH gene only yields one DH (DH44) [18]. In general, all insect DHs stimulate fluid secretion in the insect Malpighian tubules $[27,28,30]$. A DH-44 GPCR gene, CG8422, has been identified in Drosophila [75]. This GPCR gene belongs to the GPCR family B (Fig. 4). The Tribolium genome contains two orthologues of CG8422: Tc 65 and Tc 66 (Fig. 4). These Tribolium receptor genes have 6-7 introns in common with the Drosophila receptor gene (Table 3). Also the Tribolium receptor proteins have high amino acid sequence identities (53-58\%) with their Drosophila counterpart, strongly suggesting they are DH-37/47 receptors.

\subsubsection{Tc 69 is a PDF-like receptor gene}

Pigment dispersing factor (PDF) is a circadian transmitter in the insect brain, transmitting signals from the central circadian pacemaker neurons to downstream neurons and other cells involved in rhythmicity [152]. Drosophila and many other insects produce PDF [121,132], but in Tribolium we were unable to find a PDF gene [100]. Three research groups have independently identified the Drosophila gene CG13758 as the one encoding the PDF receptor $[69,91,110]$. Surprisingly, the Tribolium genome contains a gene, Tc 69 , that is the clear orthologue of CG13758 (Fig. 4). This Tribolium gene has only 2 (out of 7) introns in common with CG13758 (Table 3). The Tribolium receptor protein, however, has high amino acid sequence identity $(50 \%)$ with the Drosophila PDF receptor (Table 3 ).

\subsubsection{Tc 70 is a DH-31-like receptor gene}

As mentioned above, Tribolium has a DH-31 gene (Table 1) [100]. In Drosophila, the gene CG32843 has been identified as coding for a DH-31 receptor [76]. The Tribolium genome contains a gene, Tc 70, that is the clear orthologue of CG32843 (Fig. 4). Tc 70 has all seven introns in common with CG32843. Furthermore, the Tribolium receptor protein has a high amino acid sequence identity (54\%) with the Drosophila DH31 receptor, strongly suggesting that Tc 70 is a DH-31 receptor gene (Table 3 ).

4.2. No ligands can be assigned for twenty-one neuropeptide and protein hormone GPCRs

No ligands (highlighted in blue) can be assigned for Tc 22, Tc 23, Tc 24, Tc 27, Tc 28, Tc 36, Tc 37, Tc 39, Tc 42 (Fig. 3A), Tc 51, Tc 55, Tc 56, Tc 60-64 (Fig. 3B), Tc 67, Tc 68, Tc 71, and Tc 72 (Fig. 4). The ligand for Tc 45 (highlighted in green in Fig. 3B) is discussed in paragraph 7 .

\section{Neurohormone GPCR gene losses in Tribolium compared to Drosophila}

Tribolium has apparently lost the tyramine GPCR gene, present in both Drosophila (GC7431) [23] and honey bee (Am 13) (Fig. 2). Furthermore, it has lost the kinin GPCR gene, again present in both Drosophila (CG10626) [131] and honey bee (Am 33) (bottom of Fig. 3A). This last loss fits very well with the absence of the kinin peptide in Tribolium (Table 1) [100]. Tribolium has also lost the corazonin GPCR gene present in both Drosophila (CG10698) [20] and the honey bee (Am 45) (top Fig. 3B). Again, this agrees very well with the absence of the corazonin peptide in Tribolium (Table 1) [100]. Surprisingly, Tribolium has lost the allatostatinA GPCR gene, of which 2 copies (paralogues) are present in Drosophila (CG2872 and CG10001) [10,90,95-97] and one copy in the honey bee (Am 30) (middle of Fig. 3B). Also this fits very well with the absence of allatostatin-A peptides in Tribolium (Table 1) [100]. 


\section{Neurohormone GPCR gene duplications in Tribolium compared to Drosophila}

In the ancestors of Tribolium, neurohormone GPCR gene duplications have occurred that are not present in the honey bee or Drosophila. These duplications might be specific for the order Coleoptera or the family Tenebrinoidae, to which Tribolium belongs, and of which many species are drought-resistant. Duplication can be seen in the group of CCAP and AKH receptor genes (top Fig. 3B), where there are two paralogues ( $\mathrm{Tc} 43$ and $\mathrm{Tc} 44$ ) for the CCAP and two paralogues (Tc 46 and Tc 47) for the AKH receptor genes. Also the GPA2/GPB5 LGR gene has duplicated in Tribolium (leading to Tc 49 and Tc 50) as well as the short neuropeptide $\mathrm{F}$ receptor gene (leading to Tc 57 and Tc 58) (Fig. 3B).

\section{Neurohormone GPCR genes that occur in Tribolium but not in other holometabolous insects with a sequenced genome: Tc 45 is a vasopressin-like receptor gene}

There are a few neurohormone GPCR genes that apparently only occur in Tribolium and not in any of the other holometabolous insects with a sequenced genome (Fig. 1). Tc 45 (highlighted in green, top Fig. 3B) belongs to them, as well as Tc 72 (bottom Fig. 4). The Tc 45 receptor belongs to the CCAP, corazonin, and AKH receptor branch and is, therefore, structurally related to any of them (top Fig. 3B). A TBLASTN search, however, revealed that the Tc 45 receptor protein is closely related to mammalian vasopressin/oxytocin receptors: $36 \%$ identity ( $46 \%$ similarity) to the mouse vasopressin $1 \mathrm{~A}$ receptor and $35 \%$ identity ( $49 \%$ similarity) to the mouse oxytocin receptor. These structural relationships of the Tc 45 receptor protein to the mammalian vasopressin/oxytocin recep- tors are clearly stronger than to the Tribolium CCAP and AKH receptors (Fig. 5, upper panel). Because we also found a vasopressin-like peptide in Tribolium (Fig. 5, lower panel) [100], Tc 45 is likely to be the Tribolium vasopressin receptor gene.

\section{General discussion}

Our current paper gives an overview (Figs. 2-4) of neurohormone GPCRs in three insect orders: Hymenoptera (honey bee), Coleoptera (Tribolium), and Diptera (Drosophila). This overview includes the most basal holometabolous insects (Hymenoptera) and the most advanced ones (Diptera) and, therefore, might give a reliable overall picture of neurohormone GPCRs present in all holometabolous insects. However, there is one caveat, namely that many insect species have adapted to ecological niches. This implicates that these insect species have special needs with respect to the neurohormone GPCRs that steer these adaptations. Thus, not all holometabolous insects might have a collection of neurohormone GPCRs that resembles that of the honey bee or Drosophila, or is an intermediate between these two collections. When we take Tribolium as an example, we can see that its biogenic amine GPCR collection is an intermediate between the situations found in the honey bee and Drosophila (Fig. 2). For the neuropeptide and protein hormone GPCRs, however, there are sometimes striking differences between Tribolium and the two other insect species. One of these differences is the existence, in Triboli$u m$, of a vasopressin peptide and its likely receptor (Tc 45), which have not been found in the honey bee, Drosophila, or any other holometabolous insect with a completely sequenced genome (six other Drosophila species, Anopheles gambiae, Aedes aegypti, Bombyx mori, Nasonia vitripennis, all highlighted in green in Fig. 1). In mammals, vasopressin

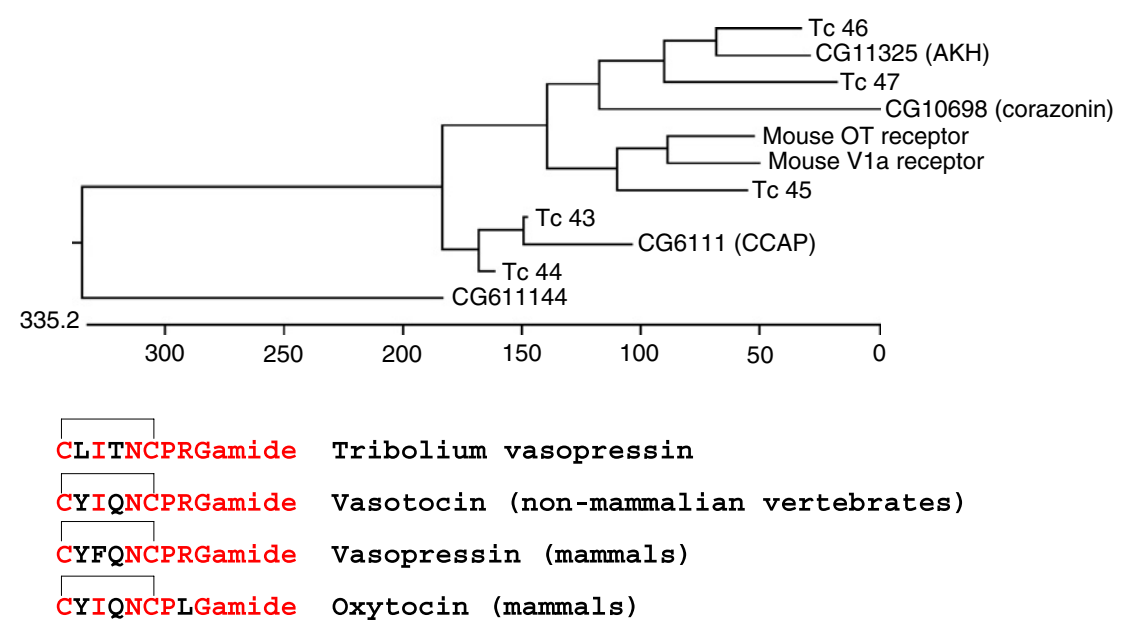

Fig. 5. Upper panel. Phylogenetic tree analysis of the Tc 43-Tc 46 receptor proteins, the mouse oxytocin (OT) receptor, the mouse vasopressin-1a (V1a) receptor, and the Drosophila AKH receptor (CG11325), corazonin receptor (CG10698), and CCAP receptor (CG6111) proteins. The analysis clearly shows that the Tc 45 protein is more closely related to the mammalian vasopressin and oxytocin receptors than to its most closely related insect receptor proteins, suggesting that it is a vasopressin/oxytocin receptor. Lower panel. That the Tc 45 protein is a vasopressin receptor is supported by the presence of a clear vasopressin-like peptide in Tribolium, whereas an oxytocin-like peptide is absent (Table 1) [100]. 


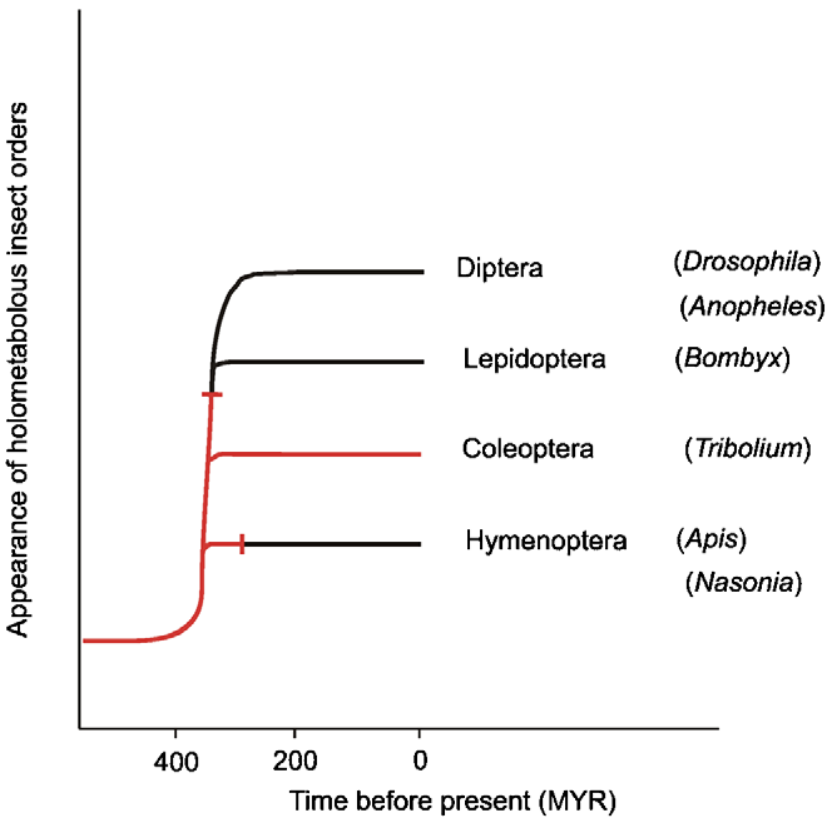

Fig. 6. A schematic representation of the evolution of the vasopressin/ receptor couple in holometabolous insects. The vasopressin/receptor couple (highlighted in red) is present in primitive holometabolous insects and continues to be so in Coleoptera. In the evolutionary line leading to Hymenoptera, this hormonal system has been abandoned (indicated by the dead-end sign) and the same event has occurred in the line leading to Lepidoptera and Diptera (again indicated by a dead-end sign).

and its receptors play a crucial role in water reabsorption in the kidneys $[6,47,86]$. It is possible that the vasopressin/ receptor couple plays a similar antidiuretic role in Triboli$u m$. A strict regulation of water homeostasis (water reabsorption) is essential for Tribolium to survive its very dry ecological niche.

A vasopressin receptor has, so far, never been found in insects or other arthropods. A vasopressin peptide, however, with an identical structure as the Tribolium vasopressin-like peptide (Fig. 5, lower panel) has previously been isolated from the locust Locusta migratoria [130]. Locusta is a hemimetabolous insect and it is interesting that, like Tribolium, it is adapted to a relatively dry ecosystem. However, a physiological role of this insect vasopressin in water homeostasis in Locusta has never been proven [29].

Vasopressin also occurs in other invertebrates, such as annelids and molluscs and vasopressin receptors have also been cloned and characterized from these animals $[78,98,154]$. These data show that the vasopressin/receptor couple is a very ancient neurohormonal system that has evolved before the split of Proto- and Deuterostomia, 640-760 million years (MYR) ago [33].

We have tried to understand the evolutionary events that have led to the presence of the vasopressin system in Tribolium, but to its absence in all the other holometabolous insects with a sequenced genome (Fig. 6). In our opinion, the ancestral insects did possess the vaso-

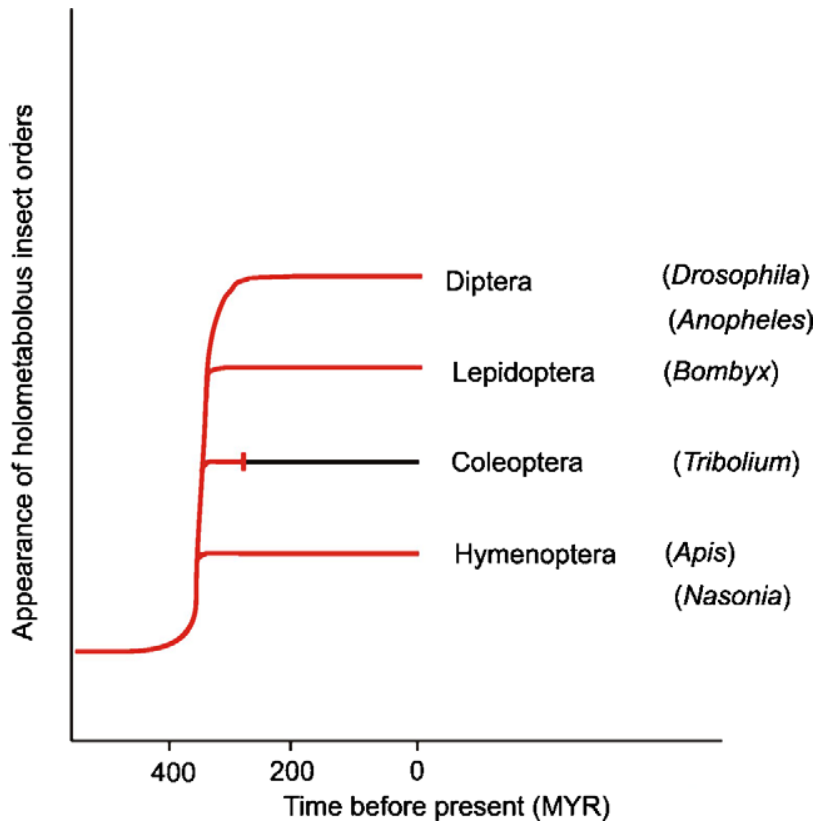

Fig. 7. A similar schematic representation as in Fig. 6, but now highlighting the corazonin/receptor couple (in red). Ancestral holometabolous insects have this hormonal system, which continues to exist in Hymenoptera, Lepidoptera, and Diptera, but which is abandoned in the evolutionary line leading to modern Coleoptera.

pressin system, but during holometabolous insect evolution it has been lost at least two times (see dead-end signs in Fig. 6).

Another striking difference between Tribolium and honey bee/Drosophila is the clear absence of certain hormonal systems. For example, corazonin has always been regarded as a very essential neuropeptide, being important for the initial steps of insect moulting by releasing ETH from the tracheal Inka cells, thereby triggering ecdysis [81,171]. Corazonin has been found in nearly all insect orders except for the Coleoptera [129]. Also, the corazonin receptors have been identified in Drosophila, Anopheles, and the honey bee (Fig. 3B) $[9,20,57]$. Tribolium, however, can apparently live without the corazonin system, as both corazonin and its receptor are lacking (Table 1; Fig. 3B, top) [100]. How is this possible?

The correct answer is currently difficult to give, but it could be that certain evolutionarily related receptor groups overlap in their physiological actions. For example, the insect CCAP, corazonin, vasopressin, and $\mathrm{AKH}$ receptors (top Fig. 3B) have apparently originated from one ancestral receptor, having one ancestral ligand. This ancestral hormonal system could have been responsible for a palette of physiological processes. After gene duplications of the ancestral receptor and its ligand, specializations could have occurred, leading to a better control of the various physiological processes, but certain overlaps could still have persisted. When, as in Tribolium, numerous receptor duplications have occurred (both the CCAP and AKH receptors have been duplicated compared to Drosophila and the 
honey bee and also a vasopressin receptor is there, while absent in Drosophila and honey bee), a fourth hormone system (corazonin) might have become superfluous and no evolutionary pressure might have existed to preserve it. In other words: one of the Tribolium CCAP, vasopressin, or AKH receptors might have overtaken the role that corazonin receptors have in other (non-coleopteran) insects.

Fig. 7 tries to depict the evolutionary events that have led to the absence of the corazonin/receptor couple in Tribolium (Coleoptera), but to its presence in all the other orders of the Holometabola. Figs. 6 and 7 are clearly two extremes. We can find other examples in Figs. 3 and 4 of such extremes, for example the absence of the allatostatin-A/receptor couple in Tribolium, but its presence in members of the other orders of Holometabola (a situation as depicted in Fig. 7) $[10,90,94,97,149]$. Again, the allatostatin-A/receptor system has an ancient evolutionary origin and it is present in the ancestor groups of insects, such as crustaceans [149].

We have always been amazed and puzzled why proctolin and its receptor are present in Drosophila [36,74], but absent in the honey bee, Anopheles, and Bombyx [57]. We can now see that the proctolin/receptor couple is, again, present in Tribolium (Tc 25, top of Fig. 3A). This finding, therefore, is a somewhat complex variant of Fig. 7, where the evolutionary lines leading to the Hymenoptera, Lepidoptera, and mosquitoes have abandoned the proctolin hormonal system, whereas it has been conserved in the other groups of holometabolous insects. Also the proctolin/receptor couple is an ancient hormonal system already occurring in crustaceans $[117,147]$, but this does apparently not hamper the Hymenoptera, Lepidoptera and mosquitoes to give up the system.

There are two lessons that we can learn from our survey of hormonal systems in holometabolous insects (Figs. 2-4). First, neuropeptide/receptor couples can easily duplicate or disappear during insect evolution. Second, Drosophila is not a good representative of all insects, because several of the hormonal systems that we now find in Tribolium (for example, vasopressin and its presumed receptor Tc 45) do not exist in Drosophila. To understand insect endocrinology, therefore, it is crucial that several insects are studied in detail. It is clear that those insects should be chosen for which a sequenced genome is or will be available (Fig. 1). These insects will be our future models for which, also, the necessary genetic tools will be developed.

\section{Acknowledgments}

We thank Ann-Beth Nørholm for typing the manuscript, and the Danish Research Agency (Research Council for Nature and Universe), Novo Nordisk Foundation, and the United States Department of Agriculture for financial support.

\section{References}

[1] M.D. Adams, S.E. Celniker, R.A. Holt, C.A. Evans, J.D. Gocayne, P.G. Amanatides, S.E. Scherer, P.W. Li, R.A. Hoskins, R.F. Galle, et al., The genomic sequence of Drosophila melanogaster, Science 287 (2000) 2185-2195.

[2] M. Altstein, Role of neuropeptides in sex pheromone production in moths, Peptides 25 (2004) 1491-1501.

[3] S. Arakawa, J.D. Gocayne, W.R. McCombie, D.A. Urquhart, L.M. Hall, C.M. Fraser, J.C. Venter, Cloning, localization, and permanent expression of a Drosophila octopamine receptor, Neuron 4 (1990) 343-354.

[4] N. Audsley, R.J. Weaver, Analysis of peptides in the brain and corpora cardiaca-corpora allata of the honey bee, Apis mellifera using MALDI-TOF mass spectrometry, Peptides 27 (2006) 512-520.

[5] S. Balfanz, T. Strünker, S. Frings, A. Baumann, A family of octopamine receptors that specifically induce cyclic AMP production or $\mathrm{Ca}^{2+}$ release in Drosophila melanogaster, J. Neurochem. 93 (2005) $440-451$.

[6] L. Bankir, Antidiuretic action of vasopressin: quantitative aspects and interaction between V1a and V2 receptor-mediated effects, Cardiovasc. Res. 51 (2001) 372-390.

[7] A.B. Barron, R. Maleszka, R.K. Vander Meer, G.E. Robinson, Octopamine modulates honey bee dance behavior, Proc. Natl. Acad. Sci. USA 104 (2007) 1703-1707.

[8] K.T. Beggs, I.S. Hamilton, P.T. Kurshan, J.A. Mustard, A.R. Mercer, Characterization of a D2-like dopamine receptor (AmDOP3) in honey bee, Apis mellifera, Insect Biochem. Mol. Biol. 35 (2005) 873-882.

[9] M. Belmont, G. Cazzamali, M. Williamson, F. Hauser, C.J.P. Grimmelikhuijzen, Identification of four evolutionarily related $G$ protein-coupled receptors from the malaria mosquito Anopheles gambiae, Biochem. Biophys. Res. Commun. 344 (2006) 160-165.

[10] N. Birgul, C. Weise, H.-J. Kreienkamp, D. Richter, Reverse physiology in Drosophila: identification of a novel allatostatin-like neuropeptide and its cognate receptor structurally related to the mammalian somatostatin/galanin/opioid receptor family, EMBO J. 18 (1999) 5892-5900.

[11] S. Birman, Arousal mechanisms: speedy flies don't sleep at night, Curr. Biol. 15 (2005) R511-R513.

[12] R.T. Birse, E.C. Johnson, P.H. Taghert, D.R. Nässel, Widely distributed Drosophila G-protein-coupled receptor (CG7887) is activated by endogenous tachykinin-related peptides, J. Neurobiol. 66 (2006) 33-46.

[13] M.B. Blackburn, R.M. Wagner, J.P. Kochansky, D.J. Harrison, P. Thomas-Laemont, A.K. Raina, The identification of two myoinhibitory peptides, with sequence similarities to the galanins, isolated from the ventral nerve cord of Manduca sexta, Regul. Pept. 57 (1995) 213-219.

[14] W. Blenau, A. Baumann, Molecular and pharmacological properties of insect biogenic amine receptors: Lessons from Drosophila melanogaster and Apis mellifera, Arch. Insect Biochem. Physiol. 48 (2001) 13-38.

[15] W. Blenau, J. Erber, A. Baumann, Characterization of a dopamine D1 receptor from Apis mellifera: cloning, functional expression, pharmacology, and mRNA localization in the brain, J. Neurochem. 70 (1998) 15-23.

[16] W. Blenau, S. Balfanz, A. Baumann, Amtyr1: characterization of a gene from honey bee (Apis mellifera) brain encoding a functional tyramine receptor, J. Neurochem. 74 (2000) 900-908.

[17] M.R. Brown, J.W. Crim, R.C. Arata, H.N. Cai, C. Chun, P. Shen, Identification of a Drosophila brain-gut peptide related to the neuropeptide Y family, Peptides 20 (1999) 1035-1042.

[18] P. Cabrero, J.C. Radford, K.E. Broderick, L. Costes, J.A. Veenstra, E.P. Spana, S.A. Davies, J.A. Dow, The Dh gene of Drosophila melanogaster encodes a diuretic peptide that acts through cyclic AMP, J. Exp. Biol. 205 (2002) 3799-3807. 
[19] G. Cazzamali, C.J.P. Grimmelikhuijzen, Molecular cloning and functional expression of the first insect FMRFamide receptor, Proc. Natl. Acad. Sci. USA 99 (2002) 12073-12078.

[20] G. Cazzamali, N.P.E. Saxild, C.J.P. Grimmelikhuijzen, Molecular cloning and functional expression of a Drosophila corazonin receptor, Biochem. Biophys. Res. Commun. 298 (2002) 31-36.

[21] G. Cazzamali, F. Hauser, S. Kobberup, M. Williamson, C.J.P. Grimmelikhuijzen, Molecular identification of a Drosophila G protein-coupled receptor specific for crustacean cardioactive peptide, Biochem. Biophys. Res. Commun. 303 (2003) 146-152.

[22] G. Cazzamali, M. Torp, F. Hauser, M. Williamson, C.J.P. Grimmelikhuijzen, The Drosophila gene CG9918 codes for a pyrokinin-1 receptor, Biochem. Biophys. Res. Commun. 335 (2005) 14-19.

[23] G. Cazzamali, D.A. Klaerke, C.J.P. Grimmelikhuijzen, A new family of insect tyramine receptors, Biochem. Biophys. Res. Commun. 338 (2005) 1189-1196.

[24] A.E. Christie, K.K. Kutz-Naber, E.A. Stemmler, A. Klein, D.I. Messinger, C.C. Goiney, A.J. Conterato, E.A. Bruns, Y.W. Hsu, L. Li, P.S. Dickinson, Midgut ephithelial endocrine cells are a rich source of the neuropeptides APSGFLGMRamide (Cancer borealis tachykinin-related peptide la) and GYRKPPFNGSIFamide (Gly1SIFamide) in the crabs Cancer borealis, Cancer magister and Cancer productus, J. Exp. Biol. 210 (2007) 699-714.

[25] O. Civelli, H.-P. Nothacker, Y. Saito, Z. Wang, S.H. Lin, R.K. Reinscheid, Novel neurotransmitters as natural ligands of orphan Gprotein-coupled receptors, Trends Neurosci. 24 (2001) 230-237.

[26] O. Civelli, GPCR deorphanizations: the novel, the known and the unexpected transmitters, Trends Pharmacol. Sci. 26 (2005) 15-19.

[27] G. Coast, The endocrine control of salt balance in insects, Gen. Comp. Endocrinol. 152 (2007) 332-338.

[28] G.M. Coast, C.S. Garside, Neuropeptide control of fluid balance in insects, Ann. N. Y. Acad. Sci. 1040 (2005) 1-8.

[29] G.M. Coast, R.C. Rayne, T.K. Hayes, A.I. Mallet, K.S. Thompson, J.P. Bacon, A comparison of the effects of two putative diuretic hormones from Locusta migratoria on isolated locust Malpighian tubules, J. Exp. Biol. 175 (1993) 1-14.

[30] G.M. Coast, S.G. Webster, K.M. Schegg, S.S. Tobe, D.A. Schooley, The Drosophila melanogaster homologue of an insect calcitonin-like diuretic peptide stimulates V-ATPase activity in fruit fly Malpighian tubules, J. Exp. Biol. 204 (2001) 1795-1804.

[31] J.F. Colas, J.M. Launay, O. Kellermann, P. Rosay, L. Maroteaux, Drosophila 5-HT2 serotonin receptor: coexpression with fushi-tarazu during segmentation, Proc. Natl. Acad. Sci. USA 92 (1995) 54415445 .

[32] H.A. Dierick, R.J. Greenspan, Serotonin and neuropeptide F have opposite modulatory effects on fly aggression, Nat. Genet. 39 (2007) 678-682.

[33] E.J.P. Douzery, E.A. Snell, E. Bapteste, F. Delsuc, H. Philippe, The timing of eukaryotic evolution: does a relaxed molecular clock reconcile proteins and fossils? Proc. Natl. Acad. Sci. USA 101 (2004) 15386-15391.

[34] D. Dulcis, R.B. Levine, J. Ewer, Role of the neuropeptide CCAP in Drosophila cardiac function, J. Neurobiol. 64 (2005) 259-274.

[35] K. Egerod, E. Reynisson, F. Hauser, G. Cazzamali, M. Williamson, C.J.P. Grimmelikhuijzen, Molecular cloning and functional expression of the first two specific insect myosuppressin receptors, Proc. Natl. Acad. Sci. USA 100 (2003) 9808-9813.

[36] K. Egerod, E. Reynisson, F. Hauser, M. Williamson, G. Cazzamali, C.J.P. Grimmelikhuijzen, Molecular identification of the first insect proctolin receptor, Biochem. Biophys. Res. Commun. 306 (2003) 437-442.

[37] K.K. Eriksen, F. Hauser, M. Schiøtt, K.-M. Pedersen, L. Søndergaard, C.J.P. Grimmelikhuijzen, Molecular cloning, genomic organization, developmental regulation, and a knock out mutant of a novel Leu-rich repeats-containing G protein-coupled receptor (DLGR-2) from Drosophila melanogaster, Genome Res. 10 (2000) 924-938.

[38] G. Feng, F. Hannan, V. Reale, Y.Y. Hon, C.T. Kousky, P.D. Evans, L.M. Hall, Cloning and functional characterization of a novel dopamine receptor from Drosophila melanogaster, J. Neurosci. 16 (1996) 3925-3933.

[39] G. Feng, V. Reale, H. Chatwin, K. Kennedy, R. Venard, C. Ericsson, K. Yu, P.D. Evans, L.M. Hall, Functional characterization of a neuropeptide F-like receptor from Drosophila melanogaster, Eur. J. Neurosci. 18 (2003) 227-238.

[40] T.J. Fort, K. Garcia Crescioni, H.J. Agricola, V. Brezina, M.W. Miller, Regulation of the crab heartbeat by crustacean cardioactive peptide (CCAP): central and peripheral actions, J. Neurophysiol. 97 (2007) 3407-3420.

[41] G. Fraenkel, C. Hsiao, Hormonal and nervous control of tanning in the fly, Science 138 (1962) 27-29.

[42] G. Fraenkel, C. Hsiao, M. Seligman, Properties of bursicon: an insect protein hormone that controls cuticular tanning, Science 151 (1966) 91-93.

[43] R. Fredriksson, H.B. Schiöth, The repertoire of G-protein-coupled receptors in fully sequenced genomes, Mol. Pharmacol. 67 (2005) $1414-1425$.

[44] G. Gäde, K.H. Hoffmann, J.H. Spring, Hormonal regulation in insects: facts, gaps, and future directions, Physiol. Rev. 77 (1997) 963-1032.

[45] S.F. Garczynski, M.R. Brown, P. Shen, T.F. Murray, J.W. Crim, Characterization of a functional neuropeptide F. receptor from Drosophila melanogaster, Peptides 23 (2002) 773-780.

[46] U. Gether, Uncovering molecular mechanisms involved in activation of G protein-coupled receptors, Endocr. Rev. 21 (2000) 90113.

[47] G. Gimpl, F. Fahrenholz, The oxytocin receptor system: structure, function, and regulation, Physiol. Rev. 81 (2001) 629-683.

[48] M. Giurfa, Associative learning: the instructive function of biogenic amines, Curr. Biol. 16 (2006) R892-R895.

[49] F. Gotzes, S. Balfanz, A. Baumann, Primary structure and functional characterization of a Drosophila dopamine receptor with high homology to human D1/5 receptors, Receptor Channels 2 (1994) 131-141.

[50] E. Grill, A. Christmann, A plant receptor with a big family, Science 315 (2007) 1676-1677.

[51] L. Grohmann, W. Blenau, J. Erber, P.R. Ebert, T. Strunker, A. Baumann, Molecular and functional characterization of an octopamine receptor from honey bee (Apis mellifera) brain, J. Neurochem. 86 (2003) 725-735.

[52] K.-A. Han, N.S. Millar, M.S. Grotewiel, R.L. Davis, DAMB, a novel dopamine receptor expressed specifically in Drosophila mushroom bodies, Neuron 16 (1996) 1127-1135.

[53] K.-A. Han, N.S. Millar, R.L. Davis, A novel octopamine receptor with preferential expression in Drosophila mushroom bodies, J. Neurosci. 18 (1998) 3650-3658.

[54] F. Hauser, H.-P. Nothacker, C.J.P. Grimmelikhuijzen, Molecular cloning, genomic organization and developmental regulation of a novel receptor from Drosophila melanogaster structurally related to members of the thyroid-stimulating hormone, follicle-stimulating hormone, luteinizing hormone/choriogonadotropin receptor family from mammals, J. Biol. Chem. 272 (1997) 1002-1010.

[55] F. Hauser, L. Søndergaard, C.J.P. Grimmelikhuijzen, Molecular cloning, genomic organization and developmental regulation of a novel receptor from Drosophila melanogaster structurally related to gonadotropin-releasing hormone receptors from vertebrates, Biochem. Biophys. Res. Commun. 249 (1998) 822-828.

[56] F. Hauser, M. Williamson, G. Cazzamali, C.J.P. Grimmelikhuijzen, Identifying neuropeptide and protein hormone receptors in Drosophila melanogaster by exploiting genomic data, Brief. Funct. Genomics Proteomics 4 (2006) 321-330.

[57] F. Hauser, G. Cazzamali, M. Williamson, W. Blenau, C.J.P. Grimmelikhuijzen, A review of neurohormone GPCRs present in the fruitfly Drosophila melanogaster and the honey bee Apis mellifera, Prog. Neurobiol. 80 (2006) 1-19.

[58] M.G. Hearn, Y. Ren, E.W. McBride, I. Reveillaud, M. Beinborn, A.S. Kopin, A Drosophila dopamine 2-like receptor: molecular 
characterization and identification of multiple alternatively spliced variants, Proc. Natl. Acad. Sci. USA 99 (2002) 14554-14559.

[59] R.S. Hewes, P.H. Taghert, Neuropeptides and neuropeptide receptors in the Drosophila melanogaster genome, Genome Res. 11 (2001) $1126-1142$.

[60] G.M. Holman, B.J. Cook, R.J. Nachman, Isolation, primary structure, and synthesis of leucomyosuppressin, an insect neuropeptide that inhibits spontaneous contractions of the cockroach hindgut, Comp. Biochem. Physiol. C 85 (1986) 329-333.

[61] G.M. Holman, B.J. Cook, R.J. Nachman, Primary structure and synthesis of a blocked myotropic neuropeptide isolated from the cockroach, Leucophaea maderae, Comp. Biochem. Physiol. C 85 (1986) 219-224.

[62] R.A. Holt, G.M. Subramanian, A. Halpern, G.G. Sutton, R. Charlab, D.R. Nusskern, P. Wincker, A.G. Clark, J.M.C. Ribeiro, R. Wides, et al., The genome sequence of the malaria mosquito Anopheles gambiae, Science 298 (2002) 129-149.

[63] T. Homma, K. Watanabe, S. Tsurumaru, H. Kataoka, K. Imai, M. Kamba, T. Niimi, O. Yamashita, T. Yaginuma, G proteincoupled receptor for diapause hormone, an inducer of Bombyx embryonic diapause, Biochem. Biophys. Res. Commun. 344 (2006) 386-393.

[64] S.Y. Hsu, K. Nakabayashi, S. Nishi, J. Kumagai, M. Kudo, O.D. Sherwood, A.J. Hsueh, Activation of orphan receptors by the hormone relaxin, Science 295 (2002) 671-674.

[65] S.Y. Hsu, K. Nakabayashi, A. Bhalla, Evolution of glycoprotein hormone subunit genes in bilateral metazoa: identification of two novel human glycoprotein hormone subunit family genes, GPA2 and GPB5, Mol. Endocrinol. 16 (2002) 1538-1551.

[66] Y.-J. Hua, Y. Tanaka, K. Nakamura, M. Sakakibara, S. Nagata, H. Kataoka, Identification of a prothoracicostatic peptide in the larval brain of the silkworm, Bombyx mori, J. Biol. Chem. 274 (1999) 31169-31173.

[67] J. Huang, Y. Zhang, M. Li, S. Wang, W. Liu, P. Couble, G. Zhao, Y. Huang, RNA interference-mediated silencing of the bursicon gene induces defects in wing expansion of silkworm, FEBS lett. 581 (2007) 697-701.

[68] M.A. Humphries, J.A. Mustard, S.J. Hunter, A. Mercer, V. Ward, P.R. Ebert, Invertebrate D2 type dopamine receptor exhibits agebased plasticity of expression in the mushroom bodies of the honeybee brain, J. Neurobiol. 55 (2003) 315-330.

[69] S. Hyun, Y. Lee, S.-T. Hong, S. Bang, D. Paik, J. Kang, J. Shin, J. Lee, K. Jeon, S. Hwang, E. Bae, J. Kim, Drosophila GPCR Han is a receptor for the circadian clock neuropeptide PDF, Neuron 48 (2005) 267-278.

[70] G. Isabel, J.R. Martin, S. Chidami, J.A. Veenstra, P. Rosay, AKHproducing neuroendocrine cell ablation decreases trehalose and induces behavioral changes in Drosophila, Am. J. Physiol. Regul. Integr. Comp. Physiol. 288 (2005) R531-R538.

[71] A. Iversen, G. Cazzamali, M. Williamson, F. Hauser, C.J.P. Grimmelikhuijzen, Molecular identification of the first insect ecdysis triggering hormone receptors, Biochem. Biophys. Res. Commun. 299 (2002) 924-931.

[72] A. Iversen, G. Cazzamali, M. Williamson, F. Hauser, C.J.P. Grimmelikhuijzen, Molecular cloning and functional expression of a Drosophila receptor for the neuropeptides capa-1 and -2, Biochem. Biophys. Res. Commun. 299 (2002) 628-633.

[73] E.C. Johnson, L.M. Bohn, L.S. Barak, R.T. Birse, D.R. Nässel, M.G. Caron, P.H. Taghert, Identification of Drosophila neuropeptide receptors by $\mathrm{G}$ protein-coupled receptors-beta-arrestin2 interactions, J. Biol. Chem. 278 (2003) 52172-52178.

[74] E.C. Johnson, S.F. Garczynski, D. Park, J.W. Crim, D.R. Nässel, P.H. Taghert, Identification and characterization of a $G$ proteincoupled receptor for the neuropeptide proctolin in Drosophila melanogaster, Proc. Natl. Acad. Sci. USA 100 (2003) 6198-6203.

[75] E.C. Johnson, L.M. Bohn, P.H. Taghert, Drosophila CG8422 encodes a functional diuretic hormone receptor, J. Exp. Biol. 207 (2004) 743-748.
[76] E.C. Johnson, O.T. Shafer, J.S. Trigg, J. Park, D.A. Schooley, J.A. Dow, P.H. Taghert, A novel diuretic hormone receptor in Drosophila: evidence for conservation of CGRP signalling, J. Exp. Biol. 208 (2005) 1239-1246.

[77] L.M. Jørgensen, F. Hauser, G. Cazzamali, M. Williamson, C.J.P. Grimmelikhuijzen, Molecular identification of the first SIFamide receptor, Biochem. Biophys. Res. Commun. 340 (2006) 696-701.

[78] A. Kanda, H. Satake, T. Kawada, H. Minakata, Novel evolutionary lineages of the invertebrate oxytocin/vasopressin superfamily peptides and their receptors in the common octopus (Octopus vulgaris), Biochem. J. 387 (2005) 85-91.

[79] K. Kawamura, S. Sudo, J. Kumagai, M. Pisarska, S.Y. Hsu, R. Bathgate, J. Wade, A.J. Hsueh, Relaxin research in the postgenomic era, Ann. N. Y. Acad. Sci. 1041 (2005) 1-7.

[80] L. Kean, W. Cazenave, L. Costes, K.E. Broderick, S. Graham, V.P. Pollock, S.A. Davies, J.A. Veenstra, J.A. Dow, Two nitridergic peptides are encoded by the gene capability in Drosophila melanogaster, Am. J. Physiol. Regul. Integr. Comp. Physiol. 282 (2002) R1297-R1307.

[81] Y.J. Kim, I. Spalovská-Valachova, K.H. Cho, I. Zitnanova, Y. Park, M.E. Adams, D. Zitnan, Corazonin receptor signalling in ecdysis initiation, Proc. Natl. Acad. Sci. USA 101 (2004) 6704-6709.

[82] S.K. Kim, E.J. Rulifson, Conserved mechanisms of glucose sensing and regulation by Drosophila corpora cardiaca cells, Nature 431 (2004) 316-320.

[83] Y.J. Kim, D. Zitnan, C.G. Galizia, K.H. Cho, M.E. Adams, A command chemical triggers an innate behaviour by sequential activation of multiple peptidergic ensembles, Curr. Biol. 16 (2006) 1395-1407.

[84] Y.J. Kim, D. Zitnan, K.H. Cho, D.A. Schooley, A. Mizoguchi, M.E. Adams, Central peptidergic ensembles associated with organization of an innate behavior, Proc. Natl. Acad. Sci. USA 103 (2006) 1421114216.

[85] K. Kimura, A. Kodama, Y. Hayasaka, T. Ohta, Activation of the cAMP/PKA signaling pathway is required for post-ecdysial cell death in wing epidermal cells of Drosophila melanogaster, Development 131 (2004) 1597-1606.

[86] Y. Kondo, T. Morimoto, T. Nishio, U.F. Aslanova, M. Nishino, E.I. Farajov, N. Sugawara, N. Kumagai, A. Ohsaga, Y. Murayama, S. Takahashi, Phylogenetic, ontogenetic, and pathological aspects of the urine-concentrating mechanism, Clin. Exp. Nephrol. 10 (2006) $165-174$.

[87] S.J. Kramer, A. Toschi, C.A. Miller, H. Kataoka, G.B. Quistad, J.P. Li, R.L. Carney, D.A. Schooley, Identification of an allatostatin from the tobacco hornworm Manduca sexta, Proc. Natl. Acad. Sci. USA 88 (1991) 9458-9462.

[88] H.J. Kreienkamp, H.J. Larusson, I. Witte, T. Roeder, N. Birgul, H.H. Honck, S. Harder, G. Ellinghausen, F. Buck, D. Richter, Functional annotation of two orphan G-protein-coupled receptors, Drostar1 and -2, from Drosophila melanogaster and their ligands by reverse pharmacology, J. Biol. Chem. 277 (2002) 39937-39943.

[89] T.M. Kubiak, M.J. Larsen, K.J. Burton, C.A. Bannow, R.A. Martin, M.R. Zantello, D.E. Lowery, Cloning and functional expression of the first Drosophila melanogaster sulfakinin receptor DSK-R1, Biochem. Biophys. Res. Commun. 291 (2002) 313-320.

[90] M.J. Larsen, K.J. Burton, M.R. Zantello, V.G. Smith, D.L. Lowery, T.M. Kubiak, Type A allatostatins from Drosophila melanogaster and Diploptera punctata activate two Drosophila allatostatin receptors, DAR-1 and DAR-2, expressed in CHO cells, Biochem. Biophys. Res. Commun. 286 (2001) 895-901.

[91] B.C. Lear, C.E. Merrill, J.-M. Lin, A. Schroeder, L. Zhang, R. Allada, A G protein-coupled receptor groom-of- $P D F$, is required for PDF neuron action in circadian behavior, Neuron 48 (2005) 221227.

[92] G. Lee, J.H. Bahn, J.H. Park, Sex- and clock-controlled expression of the neuropeptide F gene in Drosophila, Proc. Natl. Acad. Sci. USA 103 (2006) 12580-12585. 
[93] K.S. Lee, K.H. You, J.K. Choo, Y.M. Han, K. Yu, Drosophila short neuropeptide $\mathrm{F}$ regulates food intake and body size, J. Biol. Chem. 279 (2004) 50781-50789.

[94] C. Lenz, M. Williamson, C.J.P. Grimmelikhuijzen, Molecular cloning and genomic organization of an allatostatin preprohormone from Drosophila melanogaster, Biochem. Biophys. Res. Commun. 273 (2000) 1126-1131.

[95] C. Lenz, L. Søndergaard, C.J.P. Grimmelikhuijzen, Molecular cloning and genomic organization of a novel receptor from Drosophila melanogaster structurally related to mammalian galanin receptors, Biochem. Biophys. Res. Commun. 269 (2000) 91-96.

[96] C. Lenz, M. Willamson, C.J.P. Grimmelikhuijzen, Molecular cloning and genomic organization of a second probable allatostatin receptor from Drosophila melanogaster, Biochem. Biophys. Res. Commun. 273 (2000) 571-577.

[97] C. Lenz, M. Williamson, G.N. Hansen, C.J.P. Grimmelikhuijzen, Identification of four Drosophila allatostatins as the cognate ligands for the Drosophila orphan receptor DAR-2, Biochem. Biophys. Res. Commun. 286 (2001) 1117-1122.

[98] A. Levoye, B. Mouillac, G. Rivière, D. Vieau, M. Salzet, C. Breton, Cloning, expression and pharmacological characterization of a vasopressin-related receptor in an annelid, the leech Theromyzon tessulatum, J. Endocrinol. 184 (2005) 277-289.

[99] X.-J. Li, W. Wolfgang, Y.-N. Wu, R.A. North, M. Forte, Cloning, heterologous expression and developmental regulation of a Drosophila receptor for tachykinin-like peptides, EMBO J. 10 (1991) 3221-3229.

[100] B. Li, R. Predel, S. Neupert, F. Hauser, Y. Tanaka, G. Cazzamali, M. Williamson, P. Verleyen, L. Schoofs, J. Schachtner, C.J.P. Grimmelikhuijzen, Y. Park, Genomics, transcriptomics, and peptidomics of neuropeptides and protein hormones in the red flour beetle Tribolium castaneum, Genome Res. (2007), in press, doi:10.1101/gr.6714008.

[101] X. Liu, Y. Yue, B. Li, Y. Nie, W. Li, W.-H. Wu, L. Ma, A G protein-coupled receptor is a plasma membrane receptor for the plant hormone abscisic acid, Science 315 (2007) 1712-1716.

[102] M.W. Lorenz, R. Kellner, K.H. Hoffmann, A family of neuropeptides that inhibit juvenile-hormone biosynthesis in the cricket, Gryllus bimaculatus, J. Biol. Chem. 270 (1995) 21103-21108.

[103] H. Luan, W.C. Lemon, N.C. Peabody, J.B. Pohl, P.K. Zelensky, D. Wang, M.N. Nitabach, T.C. Holmes, B.H. White, Functional dissection of a neuronal network required for cuticle tanning and wing expansion in Drosophila, J. Neurosci. 26 (2006) 573-584.

[104] C.W. Luo, E.M. Dewey, S. Sudo, J. Ewer, S.Y. Hsu, H.W. Honegger, A.J. Hsueh, Bursicon, the insect cuticle-hardening hormone, is a heterodimeric cystine knot protein that activates $\mathrm{G}$ protein-coupled receptor LGR2, Proc. Natl. Acad. Sci. USA 102 (2005) 2820-2825.

[105] J.L. Maestro, R. Aguilar, N. Pascual, M.L. Valero, M.D. Piulachs, D. Andreu, I. Navarro, X. Belles, Screening of antifeedant activity in brain extracts led to the identification of sulfakinin as a satiety promoter in the German cockroach. Are arthropod sulfakinins homologous to vertebrate gastrins-cholecystokinins? Eur. J. Biochem. 268 (2001) 5824-5830.

[106] B. Maqueira, H. Charwin, P.D. Evans, Identification and characterization of a novel family of Drosophila $\beta$-adrenergic-like octopamine G-protein coupled receptors, J. Neurochem. 94 (2005) 547-560.

[107] T. Meeusen, I. Mertens, E. Clynen, G. Baggerman, R. Nichols, R.J. Nachman, R. Huybrechts, A. De Loof, L. Schoofs, Identification in Drosophila melanogaster of the invertebrate $\mathrm{G}$ protein-coupled FMRFamide receptor, Proc. Natl. Acad. Sci. USA 99 (2002) 15363-15368.

[108] F.M. Mendive, T. Van Loy, S. Claeysen, J. Poels, M. Williamson, F. Hauser, C.J.P. Grimmelikhuijzen, G. Vassart, J. Vanden Broeck, Drosophila molting neurohormone bursicon is a heterodimer and the natural agonist of the orphan receptor DLGR2, FEBS Lett. 579 (2005) 2171-2176.

[109] I. Mertens, T. Meeusen, R. Huybrechts, A. De Loof, L. Schoofs, Characterization of the short neuropeptide $F$ receptor from
Drosophila melanogaster, Biochem. Biophys. Res. Commun. 297 (2002) 1140-1148.

[110] I. Mertens, A. Vandingenen, E.C. Johnson, O.T. Shafer, W. Li, J.S. Trigg, A. De Loof, L. Schoofs, P.H. Taghert, PDF receptor signalling in Drosophila contributes to both circadian and geotactic behaviors, Neuron 48 (2005) 213-219.

[111] K. Mita, M. Kasahara, S. Sasaki, Y. Nagayasu, T. Yamada, H. Kanamori, N. Namiki, M. Kitagawa, H. Yamashita, Y. Yasukochi, K. Kadono-Okuda, K. Yamamoto, M. Ajimura, G. Ravikumar, M. Shimomura, Y. Nagamura, T. Shin-I, H. Abe, T. Shimada, S. Morishita, T. Sasaki, The genome sequence of silkworm, Bombyx mori, DNA Res. 11 (2004) 27-35.

[112] D. Monnier, J.F. Colas, P. Rosay, R. Hen, E. Borrelli, L. Maroteaux, NKD, a developmentally regulated tachykinin receptor in Drosophila, J. Biol. Chem. 267 (1992) 1298-1302.

[113] R.J. Nachman, G.M. Holman, W.F. Haddon, N. Ling, Leucosulfakinin, a sulphated insect neuropeptide with homology to gastrin and cholecystokinin, Science 234 (1986) 71-73.

[114] K. Nakabayashi, H. Matsumi, A. Bhalla, J. Bae, S. Mosselman, S.Y. Hsu, A.J. Hsueh, Thyrostimulin, a heterodimer of two new human glycoprotein hormone subunits, activates the thyroid-stimulating hormone receptor, J. Clin. Invest. 109 (2002) 1445-1452.

[115] V. Nene, J.R. Wortman, D. Lawson, B. Haas, C. Kodira, Z.J. Tu, B. Loftus, Z. Xi, K. Megy, M. Grabherr, Q. Ren, E.M. Zdobnov, et al., Genome sequence of Aedes aegypti, a major arbovirus vector, Science 316 (2007) 1718-1723.

[116] R. Nichols, Signaling pathways and physiological functions of Drosophila melanogaster FMRFamide-related peptides, Annu. Rev. Entomol. 48 (2003) 485-503.

[117] D.R. Nässel, Neuropeptides in the nervous system of Drosophila and other insects: multiple roles as neuromodulators and neurohormones, Prog. Neurobiol. 68 (2002) 1-84.

[118] T. Onai, M.G. FitzGerald, S. Arakawa, J.D. Gocayne, D.A. Urquhart, L.M. Hall, C.M. Fraser, W.R. McCombie, J.C. Venter, Cloning, sequence analysis and chromosome localization of a Drosophila muscarinic acetylcholine receptor, FEBS Lett. 255 (1989) 219-225.

[119] I. Orchard, Serotonin: a coordinator of feeding-related physiological events in the blood-gorging bug Rhodnius prolixus, Comp. Biochem. Physiol. A Mol. Integr. Physiol. 144 (2006) 316-324.

[120] J.P. Paluzzi, I. Orchard, Distribution, activity and evidence for the release of an anti-diuretic peptide in the kissing bug Rhodnius prolixus, J. Exp. Biol. 209 (2006) 907-915.

[121] J.H. Park, J.C. Hall, Isolation and chronobiological analysis of a neuropeptide pigment-dispersing factor gene in Drosophila melanogaster, J. Biol. Rhythms 13 (1998) 219-228.

[122] Y. Park, Y.J. Kim, M.E. Adams, Identification of G protein-coupled receptors for Drosophila PRXamide peptides, CCAP, corazonin, and AKH supports a theory of ligand-receptor coevolution, Proc. Natl. Acad. Sci. USA 99 (2002) 11423-11428.

[123] Y. Park, Y.J. Kim, V. Dupriez, M.E. Adams, Two subtypes of ecdysis-triggering hormone receptor in Drosophila melanogaster, J. Biol. Chem. 278 (2003) 17710-17715.

[124] J. Poels, H. Verlinden, J. Fichna, T. Van Loy, V. Franssens, K. Studizian, A. Janecka, R.J. Nachman, J. Vanden Broeck, Functional comparison of two evolutionary conserved insect neurokinin-like receptors, Peptides 28 (2007) 103-108.

[125] V.P. Pollock, J. McGettigan, P. Cabrero, I.M. Maudlin, J.A. Dow, S.A. Davies, Conservation of capa peptide-induced nitric oxide signalling in Diptera, J. Exp. Biol. 207 (2004) 4135-4145.

[126] R. Predel, S. Neupert, S. Roth, C. Derst, D.R. Nässel, Tachykininrelated peptide precursors in two cockroach species. Molecular cloning and peptide expression in brain neurons and intestine, FEBS J. 272 (2005) 3365-3375.

[127] R. Predel, C. Wegener, Biology of the capa peptides in insects, Cell. Mol. Life Sci. 63 (2006) 2477-2490. 
[128] R. Predel, R.J. Nachman, Efficacy of native FXPRLamides (pyrokinins) and synthetic analogs on visceral muscles of the American cockroach, J. Insect Physiol. 47 (2001) 287-293.

[129] R. Predel, S. Neupert, W.K. Russell, O. Scheibner, R.J. Nachman, Corazonin in insects, Peptides 28 (2007) 3-10.

[130] J.P. Proux, C.A. Miller, J.P. Li, R.L. Carney, A. Girardie, M. Delaage, D.A. Schooley, Identification of an arginine vasopressinlike diuretic hormone from Locusta migratoria, Biochem. Biophys. Res. Commun. 149 (1987) 180-186.

[131] J.C. Radford, S.A. Davies, J.A. Dow, Systematic G-protein-coupled receptor analysis in Drosophila melanogaster identifies a leucokinin receptor with novel roles, J. Biol. Chem. 277 (2002) 38810-38817.

[132] K.R. Rao, C.J. Mohrherr, J.P. Riehm, C.A. Zahnow, S. Norton, L. Johnson, G.E. Tarr, Primary structure of an analog of crustacean pigment-dispersing hormone from the lubber grasshopper Romalea microptera, J. Biol. Chem. 262 (1987) 2672-2675.

[133] S. Richards, Y. Liu, B.R. Bettencourt, P. Hradecky, S. Letovsky, R. Nielsen, K. Thornton, M.J. Hubisz, R. Chen, R.P. Meisel, et al., Comparative genome sequencing of Drosophila pseudoobscura: chromosomal, gene, and cis-element evolution, Genome Res. 15 (2005) $1-18$

[134] S. Richards, et al. (Tribolium Genome Sequencing Consortium), The first genome sequence of a beetle, Tribolium castaneum, a model for insect development and pest biology, Nature (2007) in press.

[135] T. Roeder, Tyramine and octopamine: ruling behaviour and metabolism, Annu. Rev. Entomol. 50 (2005) 447-477.

[136] C. Rosenkilde, G. Cazzamali, M. Williamson, F. Hauser, L. Sondergaard, R. DeLotto, C.J.P. Grimmelikhuijzen, Molecular cloning, functional expression, and gene silencing of two Drosophila receptors for the Drosophila neuropeptide pyrokinin-2, Biochem. Biophys. Res. Commun. 309 (2003) 485-494.

[137] F. Saudou, N. Amlaiky, J.L. Plassat, E. Borrelli, R. Hen, Cloning and characterization of a Drosophila tyramine receptor, EMBO J. 9 (1990) 3611-3617.

[138] F. Saudou, U. Boschert, N. Amlaiky, J.L. Plassat, R. Hen, A family of Drosophila serotonin receptors with distinct intracellular signalling properties and expression patterns, EMBO J. 11 (1992) 7-17.

[139] J. Savard, D. Tautz, S. Richards, G.M. Weinstock, R.A. Gibbs, J.H. Werren, H. Tettelin, M.J. Lercher, Phylogenomic analysis reveals bees and wasps (Hymenoptera) at the base of the radiation of holometabolous insects, Genome Res. 16 (2006) 1334-1338.

[140] J. Schlenstedt, S. Balfanz, A. Baumann, W. Blenau, Am5-HT7: molecular and pharmacological characterization of the first serotonin receptor of the honeybee (Apis mellifera), J. Neurochem. 98 (2006) 1985-1998.

[141] L. Schoofs, G.M. Holman, T.K. Hayes, R.J. Nachman, A. De Loof, Isolation, identification and synthesis of locustamyoinhibiting peptide (LOM-MIP), a novel biologically active neuropeptide from Locusta migratoria, Regul. Pept. 36 (1991) 111-119.

[142] S. Schöller, M. Belmont, G. Cazzamali, F. Hauser, M. Williamson, C.J.P. Grimmelikhuijzen, Molecular identification of a myosuppressin receptor from the malaria mosquito Anopheles gambiae, Biochem. Biophys. Res. Commun. 327 (2005) 29-34.

[143] C. Schroll, T. Riemensperger, D. Bucher, J. Ehmer, T. Voller, K. Erbguth, B. Gerber, T. Hendel, G. Nagel, E. Buchner, A. Fiala, Light-induced activation of distinct modulatory neurons triggers appetitive or aversive learning in Drosophila larvae, Curr. Biol. 16 (2006) 1741-1747.

[144] R.A. Shapiro, B.T. Wakimoto, E.M. Subers, N.M. Nathanson, Characterization and functional expression in mammalian cells of genomic and cDNA clones encoding a Drosophila muscarinic acetylcholine receptor, Proc. Natl. Acad. Sci. USA 86 (1989) 9039-9043.

[145] D.P. Srivastava, E.J. Yu, K. Kennedy, H. Chatwin, V. Reale, M. Hamon, T. Smith, P.D. Evans, Rapid, nongenomic responses to ecdysteroids and catecholamines mediated by a novel Drosophila G-protein-coupled receptor, J. Neurosci. 25 (2005) 6145-6155.
[146] J. Stables, A. Green, F. Marshall, N. Fraser, E. Knight, M. Sautel, G. Milligan, M. Lee, S. Rees, A bioluminescent assay for agonist activity at potentially any G-protein-coupled receptor, Anal. Biochem. 252 (1997) 115-126

[147] A.N. Starratt, B.E. Brown, Structure of the pentapeptide proctolin, a proposed neurotransmitter in insects, Life Sci. 17 (1975) 12531256.

[148] F. Staubli, T.J.D. Jørgensen, G. Cazzamali, M. Williamson, C. Lenz, L. Søndergaard, P. Roepstorff, C.J.P. Grimmelikhuijzen, Molecular identification of the insect adipokinetic hormone receptors, Proc. Natl. Acad. Sci. USA 99 (2002) 3446-3451.

[149] B. Stay, S.S. Tobe, The role of allatostatins in juvenile hormone synthesis in insects and crustaceans, Annu. Rev. Entomol. 52 (2007) 277-299.

[150] S. Sudo, Y. Kuwabara, J.I. Park, S.Y. Hsu, A.J. Hsueh, Heterodimeric fly glycoprotein hormone-alpha2 (GPA2) and glycoprotein hormone-beta5 (GPB5) activate fly leucine-rich repeat-containing G protein-coupled receptor-1 (DLGR1) and stimulation of human thyrotropin receptors by chimeric fly GPA2 and human GPB5, Endocrinology 146 (2005) 3596-3604.

[151] K.S. Sugamori, L.L. Demchyshyn, F. McConkey, M.A. Forte, H.B Niznik, A primordial dopamine D1-like adenylyl cyclase-linked receptor from Drosophila melanogaster displaying poor affinity for benzazepines, FEBS Lett. 362 (1995) 131-138.

[152] P.H. Taghert, O.T. Shafer, Mechanisms of clock output in the Drosophila circadian pacemaker system, J. Biol. Rhythms 21 (2006) 445-457.

[153] S. Terhzaz, P. Rosay, S.F. Goodwin, J.A. Veenstra, The neuropeptide SIFamide modulates sexual behavior in Drosophila, Biochem. Biophys. Res. Commun. 352 (2007) 305-310.

[154] R.E. Van Kesteren, C.P. Tensen, A.B. Smit, J. Van Minnen, L.F. Kolakowski, W. Meyerhof, D. Richter, H. Van Heerikhuizen, E. Vreugdenhil, W.P. Geraerts, Co-evolution of ligand-receptor pairs in the vasopressin/oxytocin superfamily of bioactive peptides, J. Biol. Chem. 271 (1996) 3619-3626.

[155] T. Van Loy, M.B. Van Hiel, H.P. Vandersmissen, J. Poels, F. Mendive, G. Vassart, J. Vanden Broeck, Evolutionary conservation of bursicon in the animal kingdom, Gen. Comp. Endocrinol. 153 (2007) 59-63.

[156] J. Vanden Broeck, Neuropeptides and their precursors in the fruitfly, Drosophila melanogaster, Peptides 22 (2001) 241-254.

[157] G. Vassart, L. Pardo, S. Costagliola, A molecular dissection of the glycoprotein hormone receptors, Trends Biochem. Sci. 29 (2004) 119-126.

[158] P. Verleyen, E. Clynen, J. Huybrechts, A. Van Lommel, L. Vanden Bosch, A. De Loof, J. Zdarek, L. Schoofs, Fraenkel's pupariation factor identified at last, Dev. Biol. 273 (2004) 38-47.

[159] P. Verleyen, J. Huybrechts, G. Baggerman, A. Van Lommel, A. De Loof, L. Schoofs, SIFamide is a highly conserved neuropeptide: a comparative study in different insect species, Biochem. Biophys. Res. Commun. 320 (2004) 334-341.

[160] Z. Wei, G. Baggerman, R. Nachman, G. Goldsworthy, P. Verhaert, A. De Loof, L. Schoofs, Sulfakinins reduce food intake in the desert locust, Schistocerca gregaria, J. Insect Physiol. 46 (2000) 1259-1265.

[161] N.M. Weinberger, Food for thought: honeybee foraging, memory, and acetylcholine, Sci. STKE. 336 (2006) pe23.

[162] G.M. Weinstock et al., Insights into social insects from the genome of the honey bee Apis mellifera, Nature 443 (2006) 931-949.

[163] M. Williamson, C. Lenz, Å.M.E. Winther, D.R. Nässel, C.J.P. Grimmelikhuijzen, Molecular cloning, genomic organization, and expression of a C-type (Manduca sexta-type) allatostatin preprohormone from Drosophila melanogaster, Biochem. Biophys. Res. Commun. 282 (2001) 124-130.

[164] M. Williamson, C. Lenz, Å.M.E. Winther, D.R. Nässel, C.J.P. Grimmelikhuijzen, Molecular cloning, genomic organization, and expression of a B-type (cricket-type) allatostatin preprohormone from Drosophila melanogaster, Biochem. Biophys. Res. Commun. 281 (2001) 544-550. 
[165] P. Witz, N. Amlaiky, J.L. Plassat, L. Maroteaux, E. Borrelli, R. Hen, Cloning and characterization of a Drosophila serotonin receptor that activates adenylate cyclase, Proc. Natl. Acad. Aci. USA 87 (1990) 8940-8944.

[166] Q. Xia, Z. Zhou, C. Lu, D. Cheng, F. Dai, B. Li, P. Zhao, X. Zha, T. Cheng, C. Chai, et al., A draft sequence for the genome of the domesticated silkworm (Bombyx mori), Science 306 (2004) 19371940.

[167] N. Yamanaka, Y.J. Hua, A. Mizoguchi, K. Watanabe, R. Niwa, Y. Tanaka, H. Kataoka, Identification of a novel prothoracicostatic hormone and its receptor in the silkworm Bombyx mori, J. Biol. Chem. 280 (2005) 14684-14690.

[168] N. Yamanaka, D. Zitnan, Y.J. Kim, M.E. Adams, Y.J. Hua, Y. Suzuki, M. Suzuki, A. Suzuki, H. Satake, A. Mizoguchi, K. Asaoka,
Y. Tanaka, H. Kataoka, Regulation of insect steroid hormone biosynthesis by innervating peptidergic neurons, Proc. Natl. Acad. Sci. USA 103 (2006) 8622-8627.

[169] A. Yasuda, Y. Yasuda-Kamatani, M. Nozaki, T. Nakajima, Identification of GYRKPPFNGSIFamide (crustacean-SIFamide) in the crayfish Procambarus clarkii by topological mass spectrometry analysis, Gen. Comp. Endocrinol. 135 (2004) 391-400.

[170] D. Zitnan, T.G. Kingan, J.L. Hermesman, M.E. Adams, Identification of ecdysis-triggering hormone from an epitracheal endocrine system, Science 271 (1996) 88-91.

[171] D. Zitnan, Y.J. Kim, I. Zitnanová, L. Roller, M.E. Adams, Complex steroid-peptide-receptor cascade controls insect ecdysis, Gen. Comp. Endocrinol. 153 (2007) 88-96. 